REJ - Revista de Estudios de la Justicia - No 1 - Año 2002

\title{
LAS MEDIDAS CAUTELARES PERSONALES EN EL NUEVO CÓDIGO PROCESAL PENAL CHILENO
}

\author{
Juan Carlos Marín González**
}

\begin{abstract}
1. Planteamiento. 2. Características que informan las medidas cautelares: 2.1. Provisionalidad; 2.2. Instrumentalidad. 3. Presupuestos de aplicación de las medidas cautelares: 3.1. Fumus boni iuris; 3.2. Periculum in mora; 3.3. Caución o contracautela. 4. Las medidas cautelares y el derecho a un proceso sin dilaciones indebidas. 5. Las medidas cautelares personales en el proceso penal: 5.1. Planteamiento; 5.2. Principios; 5.3. Medidas específicas: 5.3.1. Citación: 5.3.1.1. Naturaleza; 5.3.1.2. Regulación; 5.3.2. Detención: 5.3.2.1. Regulación; 5.3.2.2. Naturaleza; 5.3.2.3. Casos en que procede; 5.3.2.5. Comparecencia judicial; 5.3.2.6. Derechos del detenido: 5.3.3. Prisión preventiva: 5.3.3.1. Planteamiento; 5.3.3.2. Regulación; 5.3.3.3. Significado y naturaleza; 5.3.3.4. Principios; 5.3.3.5. Presupuestos de aplicación; 5.3.3.6. Procedimiento de adopción de la prisión preventiva; 5.3.3.7. Lugar; 5.3.3.8. Tiempo; 5.3.3.9. Efectos de la medida; 5.3.3.10. Incomunicación; 5.3.3.11. Sustitución de la prisión preventiva por otras medidas cautelares; 5.3.3.12. Reemplazo de la prisión preventiva por una caución económica; 5.3.3.13. Ejecución de las cauciones; 5.3.3.14. Cancelación de la caución; 5.3.3.15. Recursos; 5.3.3.16. Término de la prisión preventiva; 5.3.4. Otras medidas cautelares personales: 5.3.4.1. Casos en que proceden; 5.3.4.2. Enumeración; 5.3.4.3. Oportunidad; 5.3.4.4. Suspensión temporal de la medida. Conclusión.
\end{abstract}

\section{Planteamiento}

El Nuevo Código Procesal Penal de Chile (NCPP) en el título V, de su libro I, bajo la denominación de Medidas Cautelares Personales, regula una serie de medidas que puede adoptar el juez de garantía, previa instancia de parte, por medio de las cuales puede restringir —en algunos casos drásticamente - la libertad ambulatoria de un individuo imputado en la comisión de un ilícito penal. Por su parte, en el título VI de su libro I, bajo la denominación de Medidas Cautelares Reales, efectúa una remisión general a las medidas precautorias contempladas en el titulo V del libro II del Código de Procedimiento Civil (CPC), y a la reglamentación que de las medidas prejudiciales realiza el título IV del libro II del aludido CPC.

De esta manera, el NCPP recoge una distinción elaborada por la doctrina comparada $^{1}$ entre, por una parte, medidas cautelares personales, propias de la pretensión punitiva que se hace valer en todo proceso penal y, por la otra, medidas cautelares reales, propia de la pretensión civil que se puede insertar dentro del proceso criminal. Al respecto, debemos tener presente que la noción misma medida o providencia cautelar, en cuanto concepto genérico bajo que el cual se engloban una serie de medidas que presentan similares características y presupuestos, fue una noción que surgió de la mano de la

*Juan Carlos Marín González, es investigador del Centro de Estudios de la Justicia, Facultad de Derecho, Universidad de Chile. Doctor en Derecho de la Universidad Carlos III de Madrid.

1 Vid. LeOne, Tratado de derecho procesal penal, t. II, trad. de Santiago Sentis Melendo, Buenos Aires, 1963, págs. 260 y ss.; Alcalá Zamora y LeVene, Derecho procesal penal, t. II, Buenos Aires, 1945, págs. 271 y ss.; FeneCH, Derecho procesal penal, v. $2^{\circ}$, Barcelona, 1960, págs. 811 y ss. Este último autor señala que «los actos procesales cautelares se pueden dividir en dos grandes grupos, según que tiendan a limitar la libertad individual o a limitar la libertad de disposición sobre un patrimonio. A los primeros les llamaremos actos cautelares personales, y a los segundos, actos cautelares reales». Ob. cit. pág. 815. 
moderna ciencia procesal y que alcanzó en la Escuela italiana de derecho procesal, de la primera mitad del siglo XX, su más brillante expresión ${ }^{2}$.

Esta noción aglutinó figuras que presentaban elementos comunes (secuestro conservativo, embargo preventivo, anotación preventiva, interventor judicial, entre las más destacadas) y les otorgó un sentido de unidad del cual carecieron durante todo el siglo $\mathrm{XIX}^{3}$. Sobre la base de este esfuerzo se fueron reconociendo por la doctrina, posteriormente también por los tribunales, una serie de principios, características y presupuestos que han informado a la tutela cautelar durante el siglo XX y que han permitido establecer un marco teórico más o menos común a todas estas medidas.

El paso siguiente que efectuó la doctrina fue adaptar los conceptos elaborados por la ciencia del procesal civil al ámbito del proceso penal ${ }^{4}$. Frente al excesivo tiempo que empleaban (y que emplean, por cierto) los tribunales de justicia en la resolución del conflicto de naturaleza penal, se fueron estudiando bajo una misma denominación todas aquellas medidas (detención, prisión preventiva, libertad provisional, arraigo, entre las más significativas) que de una u otra forma limitaban la libertad del imputado durante el desarrollo del proceso penal. El estudio de estas medidas mostró una serie de similitudes - veremos que también importantes diferencias - con las medidas cautelares que la doctrina había estudiado al interior del proceso civil. De allí que el salto natural fuese denominar a estas medidas del proceso penal bajo el mismo rótulo con el cual habían sido englobadas las providencias del proceso civil.

Con todo, es bueno tener presente que si bien la aplicación de esta construcción dogmática en la esfera del proceso penal es útil como marco de referencia, como criterio sistemático para efectuar clasificaciones y distinciones - labor, por lo demás, propia de la doctrina - debe ser matizada al menos en dos sentidos. En primer término, debemos advertir que dada la diversidad de intereses y principios que inspiran al proceso civil y al

2 Vid. Chiovenda, Principii di diritto processuale civile, 3a. ed. Napoli, 1919. Existe versión en castellano de esta tercera edición Principios de derecho procesal civil, trad. de Casais y Santaló, Madrid, 1922. CARneluTTI, «Carattere della sentenza di fallimento», en Rivista di diritto processuale civile, (1931), II, págs. 159-173. AlloRIO, «Per una nozione del processo cautelar», en Rivista di diritto processuale civile, (1936), I, págs. 18-44. CALAMANDREI, Introducción al estudio sistemático de las providencias cautelares, trad. de Sentis Melendo, Buenos Aires, 1945 (el original italiano es del año 1936). Esta última obra ha sido, sin duda, la que mayor influencia ha ejercido en la literatura procesal española y de Iberoamérica.

${ }^{3}$ De allí que no sea extraño que los códigos del siglo XIX no hayan regulado de una manera uniforme y global esta materia, sino que, por el contrario, se hayan limitado a reconocer diversas figuras dispersas en sus respectivos articulados. La legislación italiana, en este sentido, no contenía una regulación general de las medidas cautelares que, incluso, eran calificadas de manera diversa en numerosas disposiciones diseminadas en los Códigos. En la Ley de enjuiciamiento civil española de 1881 ni siquiera existió un libro o título con esa rúbrica («medidas cautelares») limitándose el título XIV del libro II a regular el embargo preventivo, el aseguramiento de bienes litigiosos y la denominada potestad cautelar genérica. La Ordenanza procesal civil alemana (ZPO) de 1877, por su parte, si bien reguló en el libro cuarto el embargo preventivo y las medidas provisionales de derechos en peligro, tampoco efectuó una reglamentación genérica del proceso cautelar el cual, por otro lado, fue subvalorado por la doctrina alemana que lo concibió como un mero apéndice del derecho de ejecución.

${ }^{4}$ Observa ORTELLS, refiriéndose al estudio de las medidas cautelares en el proceso penal español: «Dos son los problemas fundamentales que afrontamos en estas notas: la posibilidad de aplicar la teoría general de las medidas cautelares a determinadas medidas que se adoptan en el proceso penal [...]». Respondiendo afirmativamente este primer problema: «En principio siguiendo a Calamandrei y a Fairen, entendemos que es correcto, teóricamente, encuadrar determinadas actuaciones del proceso penal en la categoría de las medidas cautelares, inicialmente configurada en el ámbito del proceso civil». «Para una sistematización de las medidas cautelares en el proceso penal», en Revista General de Legislación y Jurisprudencia, No 5 (1978), pág. 440. 
proceso penal, la distinta posición y naturaleza de los sujetos que intervienen en cada uno de ellos, y, en definitiva, las particularidades propias de un proceso y otro, la teoría de las medidas cautelares no puede aplicarse sin más al proceso penal sino que requiere de una necesaria adaptación ${ }^{5}$. En segundo lugar, es evidente que el empleo de este marco teórico puede variar en los diversos ordenamientos jurídicos; así, la disímil forma como se regula una u otra institución, las desigualdades en los presupuestos de una y otra medida, la distinta forma como cada legislador implementa su aplicación, son todos factores que pueden conducir a que mientras en algunos ordenamientos una determinada actuación sea una medida cautelar, en otros no tenga esta naturaleza, o, al menos, no la tenga respecto de todas las hipótesis previstas por el legislador.

Teniendo presente estas dos prevenciones, a continuación veremos a grandes trazos el marco teórico elaborado por la ciencia del proceso civil en este ámbito. En este sentido mostraremos las características que en la actualidad la doctrina acepta sin mayor discusión como integrantes de las medidas cautelares, y los presupuestos que se requieren para su concesión. La finalidad que busca esta mirada es familiarizar al lector con lo que ha sido la formulación doctrinal en esta materia, e intentar mostrar las diferencias en su aplicación al proceso penal.

\section{CARACTERÍSTICAS QUE INFORMAN LAS MEDIDAS CAUTELARES}

Fue CALAMANDREI quién en ese afán sistematizador que impregnó gran parte de su obra, intentó establecer cuáles eran los caracteres diferenciales en virtud de los cuales las providencias cautelares se distinguían de todas las otras providencias jurisdiccionales. ${ }^{6}$ La discusión desde entonces ha sido intensa y en ocasiones poco fructífera. Prácticamente cada autor que se ha ocupado de este tema, dependiendo de la distinta regulación positiva, ha reconocido unas determinadas características y ha desechado otras ${ }^{7}$. Con todo, hoy en

5 Así, en 1945 observaba AlCALÁ ZAmora que «la adopción de las medidas o proveimientos cautelares, asegurativos o precautorios (ya que los dos sustantivos y los tres adjetivos citados se emplean indistintamente), constituye un conjunto de actuaciones al que la más moderna doctrina propende a caracterizar como proceso $[\ldots .]$.$» , agregando que «el proceso cautelar tiene en materia penal tanto o más importancia que en el orden civil,$ y si bien su finalidad es la misma, presenta ciertas diferencias específicas [...]». Derecho procesal..., ob. cit., págs. 271 y 272.

${ }^{6}$ Introducción..., ob. cit., pág. 33.

${ }^{7}$ En Chile, por ejemplo, ANABALÓN señala las siguientes características: esencialmente provisorias, limitativas, protectoras, sustituibles. El juicio ordinario de mayor cuantía, Santiago (Chile), 1954, págs. 58-62; RoJAS, por su parte, señala como características de las medidas cautelares las siguientes: provisorias, sustituibles, protectoras de la acción entablada, limitadas y no taxativas. Las medidas precautorias, Concepción, 1965., págs. 44-62; QUEZADA, por su parte, señala como características el que sean: actos procesales de parte, instrumentales, esencialmente provisionales, acumulables, sustituibles, limitadas, no taxativas. Medidas Prejudiciales y precautorias, Santiago, (Chile), 1987, págs. 102 y 103. TAVOLARI, por su parte, señala como característica de la cautela judicial, la instrumentalidad, la provisionalidad, la homogeneidad, la idoneidad, la unilateralidad. «La orden de no innovar en el recurso de protección», en Justicia, N III (1992), págs. 690-693. En España, por ejemplo, GUTIÉRREZ DE CABIEDES, ve en el efecto asegurativo de la medida, en la preordenación a un proceso pendiente, en la exhibición del título, en la homogeneidad con las medidas ejecutivas, en el carácter dispositivo, en la contracautela y en la modificalidad de las medidas, «aquellos elementos que debe constar una medida para que quepa conceptuarla de cautelar». "Elementos esenciales para un sistema de medidas cautelares», en El sistema de medidas cautelares, IX reunión de profesores de derecho procesal de las universidades españolas, Pamplona, 1974, págs. 12-18; SERRA, ve en la instrumentalidad, en la temporalidad y en la homogeneidad, pero no identidad con las medidas ejecutivas, los elementos configuradores de la tutela cautelar. SERRA-RAMOS, Las medidas cautelares en el proceso civil, Barcelona, 1974, págs. 14-21. FONT SERRA, por su parte, reduce todas estas características a dos: instrumentalidad y provisionalidad, que «guardan entre ellas una relación de interconexión e intercomunicación. Los demás caracteres que la doctrina atribuye a la tutela 
día existe relativo consenso en reconocer como elementos uniformes de estas medidas la provisionalidad y la instrumentalidad de las mismas. Estos caracteres se aplican sin mayores reparos a las denominadas medidas cautelares penales por lo que a su respecto no será necesario introducir ningún matiz diferenciador.

\subsection{Provisionalidad}

En la doctrina italiana CHIOVENDA fue uno de los primeros en reparar sobre esta característica. Señalaba el profesor romano que «en la medida provisional es necesario pues distinguir su justificación actual, esto es, frente a las apariencias del momento y su justificación última. La medida provisional actúa una efectiva voluntad de la ley, pero una voluntad que consiste en garantizar la actuación de otra supuesta voluntad de la ley: si después, por ejemplo, esta otra voluntad se ha demostrado inexistente, también la voluntad actuada con la medida provisional se manifiesta como una voluntad que no habría debido existir. La acción aseguradora es, pues, ella misma una acción provisionali ${ }^{8}$. Por su parte, para CALAMANDREI la cualidad de provisoria dada a las providencias cautelares quiere significar en sustancia lo siguiente: «que los efectos jurídicos de las mismas no sólo tienen duración temporal (fenómeno que, bajo un cierto aspecto, se puede considerar común a todas las sentencias pronunciadas, como se dice, con la cláusula rebus sic stantibus [...]) sino que tienen duración limitada a aquel período de tiempo que deberá transcurrir entre la emanación de la providencia cautelar y la emanación de otra providencia jurisdiccional, que, en la terminología común, se indica, en contraposición a la calificación de cautelar, con la calificación de definitivas? 9 .

Es decir, para la doctrina comparada las providencias cautelares están a la espera de que en el proceso de cognición ordinario se dicte la providencia definitiva, o providencia principal en el lenguaje de Calamandrei, y una vez que ésta ha alcanzado firmeza la finalidad de aquella se habrá logrado y, por lo tanto, necesariamente cesará en sus efectos. Lo anterior es precisamente lo que define esta característica, esto es, que las medidas cautelares no tienen vocación de perdurar indefinidamente en el tiempo, sino que son provisionales en su naturaleza y no aspiran jamás a convertirse en definitivas.

cautelar [...] se fundamentan y apoyan en la instrumentalidad y en la provisionalidad». «Las medidas cautelares como manifestación de la justicia preventiva», en El sistema de medidas cautelares, IX reunión de profesores de derecho procesal de las universidades españolas, Pamplona, 1974, pág. 143.

8 Principios..., ob. cit., pág. 262. CARNELUTTI también había advertido sobre el carácter provisional de las medidas cautelares al interior del Derecho italiano; así, contestando a Candian observa que en opinión de este autor «la sentencia de quiebra no es una medida ejecutiva, ni tampoco [...] una providencia jurisdiccional; pero sí una medida asegurativa. Entonces, tertium datur?». Continúa observando CARNELUTTI que existe aquí ante todo «una gran cuestión de sistema, entorno a la cual esta bien, de una buena vez, ser claros. Candian no tiene todas las razones ... si se pierde un poco en el laberinto de una fenomenología jurídica, que nuestra doctrina no ha clasificado aún con cuidado. Yo mismo, hablando del proceso cautelar en el segundo volumen de mis lecciones, no estoy muy seguro de haber podido definir su posición respecto del proceso jurisdiccional y del proceso ejecutivo; y aquello que he dicho después, en el quinto y en el sexto volumen, sobre este lado del argumento puede no ser así conocido que Candian no le habría podido ver la esperada utilidad. Un hecho es que el proceso cautelar no constituye tanto un tercer tipo de proceso al lado del proceso de cognición y del proceso de ejecución, cuanto una subespecie de esto y de aquello. El carácter de subespecie se encuentra en la composición provisional antes que en la composición definitiva de la disputa. En otras palabras, según mi opinión resulta menos eficaz, en la provisionalidad de la comprobación o de la modificación del patrimonio del deudor [...]». «Carattere... », ob. cit., pág. 165. (El destacado es mío).

${ }_{9}^{9}$ Introducción..., ob. cit., págs. 36 y 37. 


\subsection{Instrumentalidad}

En la doctrina italiana fue CALAMANDREI quien, una vez más, precisó lo que en el ámbito cautelar se entiende por la presente característica, erigiéndola, de paso, en el rasgo diferenciador de las medidas cautelares. Nos indica el maestro de Florencia, en una cita obligada en esta materia, que el carácter verdaderamente típico de las providencias cautelares es que «nunca constituyen un fin por sí mismas, sino que están ineludiblemente preordenadas a la emanación de una ulterior providencia definitiva, el resultado práctico de la cual aseguran preventivamente. Nacen, por decirlo así, al servicio de una providencia definitiva, con el oficio de preparar el terreno y de aprontar los medios más aptos para su éxito» ${ }^{10}$. En este sentido, las medidas cautelares nunca constituyen un fin en sí mismas sino que siempre están sujetas a otra providencia cuyos resultados aseguran interinamente.

El carácter instrumental de las medidas cautelares lleva necesariamente a que las medidas cautelares se extingan cuando se pronuncia la providencia principal y ésta desarrolle su eficacia ejecutiva. Si la sentencia ha reconocido el derecho reclamado por el demandante la medida cautelar habrá cumplido su propósito y entrará a producir pleno efecto el carácter ejecutivo de la resolución. Por el contrario, si la demanda es desestimada la medida perderá toda su eficacia y desaparecerá del orden procesal ${ }^{11}$.

\section{PRESUPUESTOS DE APLiCACión DE LAS MEdidAS CAUTELARES}

Para conceder una de estas medidas hay dos puntos a los que debe referirse el conocimiento del juez. En sede cautelar dos son los presupuestos normativos que deben concurrir para que un tribunal pueda otorgar una providencia de esta naturaleza. Dichos presupuestos, que debe acreditar quién solicita la medida, han sido tradicionalmente recogidos bajo las expresiones latinas fumus boni iuris y periculum in mora. A ellos se suele agregar como tercer elemento, aun cuando en estricto rigor no es un presupuesto de concesión, la caución o contracautela ${ }^{12}$. Al analizar cada uno de ellos indicaremos qué ocurre en el proceso penal.

10 Calamandrei, Introducción ..., ob. cit., pág. 44. Dentro de la doctrina española y una vez iniciado el estudio científico de las medidas cautelares desde DE LA PLAZA en adelante, no se conoce divergencia de opinión en cuanto a esta propiedad. Vid., entre otros, FAIREN, «La reforma del proceso cautelar español», en Temas del ordenamiento procesal, t. II, Madrid, 1969, pág. 899. ORTELLS-CALDERÓN CUADRADO, La tutela judicial cautelar en el derecho español, Granada, 1996, pág. 8. En Argentina vid. NovellinO, Embargo y desembargo y demás medidas cautelares, Buenos Aires, 1992, pág. 30. Martínez Boto, Medidas cautelares, Buenos Aires, 1990, pág. 77. Dentro de la escasa literatura en contra vid: Rocco, Tratado de Derecho Procesal Civil, vol. V, parte especial proceso cautelar, Bogotá-Buenos Aires, 1977, págs. 60 y ss.

11 Dentro de los textos positivos chilenos, el que recoge con extraordinaria exquisitez este planteamiento doctrinal es el actual art. 382 del Código de Procedimiento Penal (CPP) que, a propósito de la figura del embargo, señala: «Por el embargo quedan afectados bienes del procesado o del inculpado, o de terceros civiles responsables, para asegurar las responsabilidades pecuniarias que contra ellos puedan declararse. En tanto estas responsabilidades no se pronuncien por sentencia firme el embargo tendrá carácter cautelar, pero ejecutoriada la sentencia los bienes embargados serán realizados para la satisfacción de aquéllas». (El destacado es mío).

12 Obsérvese como la Nueva Ley de Enjuiciamiento Civil Española 1/2000, vigente desde el 8 de enero de 2001, recoge expresa y didácticamente esta elaboración doctrinal. Así dispone el art. 728: «Peligro por la mora procesal. Apariencia de buen derecho. Caución. 1. Sólo podrán acordarse medidas cautelares si quien las solicita justifica, que, en el caso de que se trate, podrían producirse durante la pendencia del proceso, de no adoptarse las medidas solicitadas, situaciones que impidieren o dificultaren la efectividad de la tutela que pudiere otorgarse en una eventual sentencia estimatoria. [...]. 2. El solicitante de medidas cautelares también habrá de presentar los datos, argumentos y justificaciones documentales que conduzcan a fundar, por parte del tribunal, sin prejuzgar el fondo del asunto, un juicio provisional e indiciario favorable al fundamento de su 


\subsection{Fumus boni iuris (apariencia de buen derecho)}

Tratándose de este elemento el tribunal debe verificar en una primera y provisional aproximación que el demandante tiene probabilidades de obtener una sentencia de fondo favorable. CALAMANDREI a este respecto exige cierta veracidad en la pretensión; así, observa que «por lo que se refiere a la investigación sobre el derecho, la cognición cautelar se limita en todos los casos a un juicio de probabilidades y de verosimilitud $\rangle^{13}$. ROCCO, por su parte, observa que «toda cognición sumaria y superficial importa, no la certeza del derecho, sino la posibilidad o la probabilidad de la existencia del derecho, valorada sobre la base de la afirmación por parte del pretendido titular de él y sobre elementos indiciarios, más que en verdaderas pruebas, de donde resulta probable la existencia de un derecho, cuya plena declaración de certeza será o podrá ser objeto de una plena y formal declaración de certeza del derecho» ${ }^{14}$.

En el proceso penal el presupuesto del fumus se formula desde una óptica completamente distinta; se configura no por la probabilidad de obtener una resolución favorable sobre el fondo del asunto, sino por la probabilidad de que el sujeto en contra de quién se dirige la investigación haya tenido una participación como autor cómplice o encubridor en un hecho que reviste caracteres de delito. Como afirma ORTELLS, «existe fumus boni iuris cuando, como resultado de la investigación sumarial aparecen elementos suficientes para imputar fundadamente a una persona la comisión de un delito» ${ }^{15}$. De allí que parte de la doctrina comparada denomine a este presupuesto fumus comisi delicti por que en «la adopción de una medida cautelar no se aventura un juicio sobre la existencia de ningún buen derecho, sino sobre la posible participación de una persona en un hecho delictivo» ${ }^{16}$.

\subsection{Periculum in mora (peligro en la demora)}

La medida cautelar requiere para ser concedida la existencia de un peligro inminente de daño jurídico. A causa de esta situación la medida cautelar debe ser expedida de inmediato, sin demora, es decir, en forma urgente ya que de lo contrario el daño temido se transformaría en daño efectivo, o se agravaría el daño ya producido. RoCCO observa acertadamente que el periculum no consiste en «el peligro del retardo de la providencia definitiva, sino en la posibilidad de que en el período de tiempo necesario para la realización de los intereses tutelados por el derecho mediante el ejercicio de la función

pretensión. En defecto de justificación documental, el solicitante podrá ofrecerla por otros medios. 3. Salvo que expresamente se disponga otra cosa, el solicitante de la medida cautelar deberá prestar caución suficiente para responder, de manera rápida y efectiva, de los daños y perjuicios que la adopción de la medida cautelar pudiera causar al patrimonio del demandado. El tribunal determinará la caución atendiendo a la naturaleza y contenido de la pretensión y a la valoración que realice, según el apartado anterior, sobre el fundamento de la solicitud de la medida. La caución a que se refiere el párrafo anterior podrá otorgarse en cualquiera de las formas previstas en el párrafo segundo del apartado tercero del artículo 529».

13 Introducción..., ob. cit., pág. 77. La jurisprudencia chilena en algunas ocasiones ha acogido este criterio. Así, ha fallado que «por lo expuesto y los demás antecedentes hechos valer por las partes, por ahora la existencia del derecho reclamado en el juicio no aparece con fuertes probabilidades de verosimilitud en virtud de los comprobantes invocados por el sujeto activo de la gestión cautelar». Gaceta, N ${ }^{\circ}$ 123, (1990), pág. 37, (el destacado es mío). En la doctrina española acepta este criterio CALDERÓN CUADRADO, Las medidas cautelares indeterminadas en el proceso civil, Madrid, 1992, pág. 43. En contra vid: SERRA-RAMOs, Las medidas..., ob. cit., págs. 36 y 37.

14 Tratado..., ob. cit., pág. 98.

15 «Para una ...», ob. cit., pág. 472.

16 BanACloCHE, La libertad personal y sus limitaciones, Madrid, 1996, pág. 288. 
jurisdiccional, se verifique un evento, natural o voluntario, que suprima o restrinja tales intereses, haciendo imposible o limitado su realización por medio de los órganos jurisdiccionales» ${ }^{17}$.

Ahora bien, como ha puesto de relieve la doctrina italiana ${ }^{18}$, la configuración de este periculum en el ámbito del proceso civil es diferente según la función que desempeñe la medida cautelar. En este sentido se habla de peligro de infructuosidad y de peligro de tardanza o de retardo ${ }^{19}$. En efecto, en algunas ocasiones lo importante es que la medida cautelar asegure urgentemente la existencia de bienes o de la cosa objeto de la demanda en vista de la futura ejecución (peligro de infructuosidad). En otras, en cambio, la medida cautelar lo que busca es acelerar provisoriamente la satisfacción de la pretensión deducida porque de esperarse el completo desarrollo del juicio se pueden producir en el demandante perjuicios irreparables (peligro de retardo).

En el proceso penal el periculum in mora se configura desde una óptica diferente siendo completamente ajeno a la idea de peligro de retardo antes aludida. En materia penal no puede imponerse pena alguna sin una sentencia definitiva previa. De allí que este presupuesto se conforma por la amenaza de que durante el transcurso del proceso el imputado intente su fuga o intente destruir algún material que pueda usarse como prueba de cargo en el juicio oral. Son situaciones que de una u otra forma pueden impedir o dificultar la efectividad de la sentencia que en su momento se dicte. En el primer caso porque si el imputado no es habido será declarado rebelde con el consiguiente sobreseimiento de la causa $^{20}$; y en el segundo, porque se puede dificultar de manera importante la prueba del hecho delictivo y la participación del imputado y de sus eventuales cómplices.

\subsection{Caución o contracautela}

A los dos elementos recién vistos suele agregarse por la doctrina procesal civil un tercero constituido por la caución que debe otorgar quien solicita la medida cautelar a efectos de responder por los eventuales perjuicios que se causen a la persona del demandado. CHIOVENDA al respecto nos dice que «como la acción aseguradora es meramente provisional, la ley concede al particular, pero por su cuenta y riesgo, esto es, haciéndolo juez responsable de la existencia efectiva de su derecho a la prestación; si luego resulta que éste no existía, queda obligado a los daños, y por esto puede ser obligado a prestar caución preventiva» ${ }^{21}$. ZUCKERMAN, a propósito de las medidas cautelares al

\footnotetext{
17 Tratado..., ob. cit., pág. 77.

18 Calamandrei, Introducción..., ob. cit., págs. 71 y sgtes. Proto Pisani señala a este respecto: «Per comprendere i molti contenuti che i provvedimenti cautelari possono assumere, occorre distinguere due diverse specie di pericula in mora che la tutela cautelare può essere chiamata a neutralizzare: a) il c.d. pericolo da infruttuosità del provvedimento a cognizione piena, b) il c.d. pericolo da tardività del provvedimento a cognizione piena». Ližioni di diritto processuales civile, 2a. ed., Nápoli, 1996, pág. 660. O como ha señalado TARZIA refiriéndose a esta distinción de CALAMANDREI de peligro de infructuosidad y peligro de tardanza, «si tratta, anche qui, di una distinzione che e divenuta patrimonio comune della nostra dottrina». «La tutela cautelare», en Il nuovo processo cautelare, a cura de Giuseppe TARZIA, Padova, 1993, pág. XXVI.

${ }^{19}$ En España aceptan este criterio, entre otros, CALDERÓn CuADRADO: Las medidas ..., ob. cit., págs. 76 y 77. JovÉ, Medidas cautelares innominadas en el proceso civil, Barcelona, 1995, pág. 59.

${ }^{20} \mathrm{El}$ art. 252 señala que el juez de garantía decretará el sobreseimiento temporal en los siguientes casos: b) cuando el imputado no compareciere al procedimiento y fuere declarado rebelde, de acuerdo con lo dispuesto en los artículos 99 y siguientes.

21 Principios..., ob. cit., pág. 123.
} 
interior del proceso civil inglés, observa en relación con el igual trato que debe el tribunal dispensar a las partes de un proceso, que «el demandante puede obtener una medida provisional limitando la actuación del deudor, incluso antes de la sentencia definitiva, si demuestra que un daño irreparable puede afectar sus derechos pendiente la causa. En consecuencia, cuando los tribunales conceden una medida cautelar están protegiendo exclusivamente los intereses del demandante; de esto se sigue que si el tribunal tiene que mostrar igual interés por los derechos del demandado, debe tomar las medidas necesarias para protegerlo de cualquier agravio que pueda sufrir como consecuencia de las medidas adoptadas en favor del demandante» ${ }^{22}$.

En el proceso penal el requisito de la caución no se exige en garantía de la eventual indemnización por una medida cautelar erróneamente otorgada ${ }^{23}$. Por la naturaleza y fines del proceso penal no es fácil compatibilizar este requisito con las medidas restrictivas de la libertad que en él se adoptan. Aun en el evento de que quien solicite la medida fuere el querellante particular —en aquellos ordenamientos que, como el chileno, permiten la actuación de un querellante - no se ha planteado, ni por el legislador ni por la doctrina, que previo a otorgar la medida deba darse una caución de resultas. En esta materia en el derecho chileno frente al error del juez en la concesión de alguna de esas medidas es el Estado quién debe indemnizar al sujeto que injustamente ha sido privado de su libertad. En el ordenamiento nacional existe una disposición de rango constitucional que es en extremo exigente a la hora de perseguir la responsabilidad civil del Estado por error judicial. La prácticamente nula aplicación que esta disposición ha tenido en el foro chileno no hace sino corroborar lo severa que ha sido su reglamentación ${ }^{24}$.

Pues bien, el anterior constituye en términos muy generales el marco teórico elaborado a propósito de la tutela cautelar en el proceso civil, con los necesarios matices que hemos efectuado respecto de su aplicación en el proceso penal, y que nos servirá de marco de referencia al analizar las medidas cautelares que se reconocen en el NCPP.

\section{LAS MEDIDAS CAUTELARES Y EL DERECHO A UN PROCESO SIN DILACIONES INDEBIDAS}

Sabemos que el proceso es una secuencia de actos que deben ser desplegados en forma progresiva para arribar a la sentencia que resuelve el conflicto. Por ello es menester que en todo proceso y, particularmente, en el proceso penal se desarrolle una etapa de instrucción, prueba y juicio antes de poder dictar la sentencia que en definitiva ponga término al conflicto. ROCCO, refiriéndose a la naturaleza de la función jurisdiccional, observa que esta requiere «para su desenvolvimiento, cierto tiempo, y que la posibilidad del evento dañoso (peligro), que atenta o puede atentar contra los intereses tutelados por el derecho, existe material y jurídicamente mientras tales intereses no hayan sido

22 «Dispensation with undertaking in damages-an elementary injustice», en Civil justice quarterly, 1993, pág. 268.

23 ORTELLS refiriéndose a las objeciones que dentro de la doctrina italiana tiene la aplicación de la teoría general de las medidas cautelares civiles en el proceso penal, afirma que ellas no son convincentes porque, entre otros motivos «no es esencial para la existencia de una medida cautelar que, para su adopción, deba constituirse una contracautela». «Para una...», ob. cit., pág. 443.

${ }^{24}$ La norma aludida es el art. $19 \mathrm{~N}^{\circ} 7$ letra i) de la Constitución Política que a la letra señala: «Una vez dictado sobreseimiento definitivo o sentencia absolutoria, el que hubiere sido sometido a proceso o condenado en cualquier instancia por resolución que la Corte Suprema declare injustificadamente errónea o arbitraria, tendrá derecho a ser indemnizado por el Estado de los perjuicios patrimoniales y morales que haya sufrido. La indemnización será determinada judicialmente en procedimiento breve y sumario y en él la prueba se apreciará en conciencia». 
realizados, es decir, durante todo el tiempo necesario para la declaración de certeza, la condena y el inicio de la realización coactiva, que incide sobre la disponibilidad de los bienes» ${ }^{25}$.

Obviamente el tiempo al que se alude es el necesario y razonable a efectos de que se imparta una pronta y cumplida una administración de justicia. Una dilación indebida, esto es, una demora que se extienda más allá de lo necesario y razonable para que cumplir las funciones básicas de todo proceso, lo transforma en un medio de iniquidad que atenta contra uno de los derechos básicos de los justiciables, a saber, el derecho a un debido proceso de ley. No resulta extraño, entonces, que a lo largo de la historia se haya consagrado en una serie de estatutos el derecho a un proceso «sin dilaciones indebidas» ${ }^{26}$ o, en palabras del Pacto internacional de derechos civiles y políticos de 1966, a que la causa sea vista «en un plazo razonable» ${ }^{27}$.

Sin embargo, la realidad con la que nos enfrentamos en el proceso penal es que en la gran mayoría de los países el plazo para resolver los litigios excede con mucho lo razonable que este debiera $\operatorname{ser}^{28}$. Es aquí donde las medidas cautelares cobran especial relevancia. Frente a la alarmante dilación que se observa en la resolución de los conflictos de naturaleza penal, prácticamente la totalidad de los ordenamientos jurídicos contemplan una serie de medidas que, por una parte, limitan la libertad del imputado durante el desarrollo del proceso, y que, por la otra, congelan la libre disposición de sus bienes. Estas medidas pretenden evitar que el tiempo que necesariamente requiere todo proceso se transforme en la negación de la eficacia que el proceso debe poseer en sí. Como afirma GIMENO, «si el juicio oral pudiera realizarse el mismo día de la incoación del procedimiento penal no sería necesario disponer a lo largo del procedimiento de medida cautelar alguna. Pero desgraciadamente esta solución es utópica: el juicio oral requiere de su preparación a través de la fase instructora, en la cual se invierte, en muchas ocasiones, un excesivamente dilatado período de tiempo, durante el cual el imputado podría ocultarse a la actividad de la justicia, haciendo frustrar el ulterior cumplimiento de la sentencia. Para

25 Tratado..., ob. cit., pág. 77.

${ }^{26}$ Ya el año 1215 el Rey Juan en la Carta Magna inglesa prometía «To none shall we delay right or justice». El art. 24.1 de la Constitución Española dispone al efecto: «Todas las personas tienen derecho a obtener la tutela efectiva de los jueces y tribunales en el ejercicio de sus derechos e intereses legítimos, sin que en ningún caso, pueda producirse indefensión». Por su parte, el art. 24.2 del texto constitucional español dispone: «Asimismo, todos tienen derecho al Juez ordinario predeterminado por la ley, a la defensa y a la asistencia de letrado, a ser informado de la acusación formulada contra ellos, a un proceso público sin dilaciones indebidas y con todas las garantías a utilizar los medios de prueba pertinentes para su defensa, a no declarar contra sí mismo, a no confesarse culpables y a la presunción de inocencia» (el destacado es mío).

${ }^{27}$ El Pacto internacional de derechos civiles y políticos, aprobado por la Asamblea General de las Naciones Unidas el 16 de diciembre de 1966, en su artículo 9.3. dispone: «Toda persona detenida o presa a causa de una infracción penal será llevada sin demora ante un juez u otro funcionario autorizado por la ley para ejercer funciones judiciales, y tendrá derecho a ser juzgado dentro de un plazo razonable [...]». Por su parte, el artículo 6.1. del Convenio Europeo para la protección de los derechos humanos y de las libertades fundamentales de 1950, señala: «Toda persona tiene derecho a que su causa sea vista equitativa y públicamente en un plazo razonable por un tribunal independiente e imparcial, establecido por la ley que decidirá sobre sus derechos y obligaciones civiles, [...]».

${ }^{28}$ En el caso del Derecho español en el Libro Blanco de la Justicia, elaborado por el Consejo General del Poder Judicial, se observa que «en lo que se refiere a los problemas cuantitativos, en opinión del Consejo resulta paradigmático el de las dilaciones y la excesiva duración de los procedimientos judiciales. Sin duda, constituye éste el tema más recurrente en cualquier consideración sobre la justicia, y representa uno de los tópicos comunes y arraigados en la opinión pública [...]. Ciertamente, en todas las épocas y en todos los países, las quejas sobre la lentitud de la justicia son generales [...]. Ahora bien, en el caso español, esa queja es particularmente intensa». Libro blanco de la justicia, Consejo General del Poder Judicial, Madrid, 1997, pág. 21. 
garantizar estos efectos o la ejecución de la parte dispositiva de la sentencia surge la conveniencia de adoptar, hasta que adquiera firmeza, las medidas cautelares ${ }^{29}$.

De este modo, la doctrina reconoce al interior del proceso penal, según ya hemos avanzado, dos tipos de medidas cautelares:

a) Las medidas cautelares personales que tienen por objeto privar o limitar la libertad del imputado durante el transcurso del proceso, y que debieran cumplir estrictos fines procesales, esto es, asegurar la comparecencia del imputado al juicio oral y a la eventual ejecución de la pena ${ }^{30}$.

b) Las medidas cautelares reales que restringen los derechos patrimoniales del imputado durante el curso del proceso penal, y cuyo objetivo es asegurar el pago de la eventual indemnización de perjuicios a que pudiere ser condenado el imputado, la multa que pudiere aplicársele como sanción, y las costas y gastos del proceso.

Ya hemos adelantado que el NCPP recoge esta distinción doctrinal. En este trabajo sólo nos ocuparemos de las denominadas medidas cautelares personales.

\section{LAS MEDIDAS CAUTELARES PERSONALES EN EL PROCESO PENAL}

\subsection{Planteamiento}

El NCPP contempla, en el título V del libro I, una serie de medidas que engloba bajo la denominación genérica de medidas cautelares personales. En estricto rigor es discutible que todas encuadren en lo que en doctrina se reconocen como medidas cautelares personales según los criterios y presupuestos ya esbozados. En todo caso, más allá de esta cuestión doctrinal lo relevante en esta materia es resaltar que el legislador procesal ha creado un sistema en torno a la procedencia de estas medidas, estableciendo un claro orden de prelación en su aplicación, los fines y alcances de las mismas y la continua revisión de los presupuestos que en su momento tuvo presente el tribunal al concederlas. Del mismo modo, el legislador ha establecido importantes principios que deben guiar la actuación del juez al momento de pronunciarse por la solicitud de alguna de estas medidas, y que inspiran la aplicación práctica de las mismas.

\subsection{Principios}

Dentro de los principios que informan a la nueva legislación destacan, en primer lugar, los denominados principios básicos contenidos en título I del libro I del NCPP. A este respecto, el art. $4^{\circ}$ consagra el relativo a la presunción de inocencia bajo la fórmula de presunción de no culpabilidad: «Ninguna persona será considerada culpable ni tratada como tal en tanto no fuere condenada por una sentencia firme». La nueva normativa reconoce así uno de los postulados fundamentales de la ciencia procesal penal que nos dice que «es la culpa y no la inocencia la que debe ser demostrada; y es la prueba de la culpa - y no la de la inocencia,

${ }^{29}$ Derecho procesal penal, con Moreno Catena y Cortés Domínguez, 3a . ed., Madrid, 1999, pág. 472.

$30 \mathrm{Ya}$ veremos que en los distintos ordenamientos procesales y dependiendo de los distintos momentos históricos, las medidas cautelares han desempeñado distintos fines, no sólo procesales, sino también objetivos de prevención general y, lo que es más grave, incluso de pena anticipada. 
que se presume desde el principio- la que forma objeto del juicio» ${ }^{31}$. Lamentablemente la aplicación de este principio en Chile, tras más de ochenta años de vigencia de un sistema inquisitivo consagrado en el aun vigente Código de procedimiento penal (CPP), ha sido completamente desvirtuada. Es de esperar que bajo la nueva normativa los jueces cambien su tradicional propensión a invertir la aplicación de este principio, que los ha llevado en la práctica a presumir la culpabilidad mientras no se demuestre la inocencia ${ }^{32}$.

En segundo lugar, en del ámbito de los denominados principios básicos, el art. $5^{\circ}$ inc. $1^{\circ}$ señala: «No se podrá citar, arrestar, detener, someter a prisión preventiva ni aplicar cualquier otra forma de privación o restricción de libertad a ninguna persona sino en los casos y en la forma señalados por la constitución y las leyes». Se recoge en este artículo el principio de legalidad de las medidas privativas o restrictivas de la libertad ${ }^{33}$. Por tanto, fuera de los casos expresamente previstos en la Constitución y en las leyes, no cabe que se adopten en contra de los individuos ningún tipo de medidas que de una u otra forma afecten su libertad. El inc. $2^{\circ}$ del art. $5^{\circ}$, por su parte, refuerza esta idea al señalar la forma como deben interpretarse las medidas privativas o restrictivas de libertad: «Las disposiciones de este Código que autorizan la restricción de la libertad o de otros derechos del imputado o del ejercicio de algunas facultades serán interpretadas restrictivamente y no se podrán aplicar por analogía». Corolario lógico que todo Estado de Derecho, que se precie de tal, debe establecer en resguardo de la libertad de sus ciudadanos: interpretación restrictiva de las medidas que afecten esta libertad y prohibición de su aplicación analógica.

En tercer lugar, dentro de los principios básicos consagrados en el NCPP, el art. $9^{\circ}$ nos dice que «toda actuación del procedimiento que privare al imputado o a un tercero del ejercicio de los derechos que la Constitución asegura, o la restringiere o perturbare, requerirá de autorización judicial previa. En consecuencia, cuando una diligencia de investigación pudiere producir alguno de tales efectos, el fiscal deberá solicitar previamente autorización del juez de garantía» ${ }^{34}$. Este principio será analizado de inmediato de cara a la regulación específica que del mismo se efectúa en el art. 122 inc. $2^{\circ}$.

31 Ferrajoli, Derecho y razón, trad. VVAA, 4ª ed., Valladolid, 2000, págs. 549.

32 Recordemos que en el derecho comparado uno de los peores golpes que recibió la aplicación de este principio provino de uno de los más brillantes penalistas italianos, y autor de uno de los mejores tratados de derecho procesal penal. Me refiero a MANZINI, quien escribía en su obra: «Si es erróneo, por tanto, el criterio de que las normas procesales penales estén esencialmente dirigidas a la tutela de la inocencia, más inexacta es aún la opinión de que en el procedimeitno penal valga [...] a favor del imputado una presunción de inocencia, por la que ese mismo imputado deberá ser considerado inocente mientras no haya mediado la condena irrevocable de condena. Nada más burdamente paradójico e irracional [...]. La indicada presunción de inocencia no es justificable ni aun como correlativo de la obligación de probar la acusación que incumbe al acusador, ya porque de esta obligación no se sigue necesariamente que el imputado deba presumirse inocente, toda vez que la acusación misma está ya en parte probada por indicios que determinan la imputación, ya porque la prueba de la delincuencia puede adquirirse por iniciativa del juez, ya, en fin, porque normalmente ocurre que el imputado mismo trate de probar su propia inocencia a fin de destruir precisamente los elementos de prueba de la culpabilidad sobre los que se levantó la culpabilidad. Tratado de derecho procesal penal, trad. de Santiago Sentís Melendo y Marino Ayerra Redín, t. I, Buenos Aires, 1951, págs. 253 y 255. Vid. en contra la magnífica réplica de FERRAJOLI, Derecho..., ob. cit., págs. 549 y ss.

33 Principio ya consagrado en nuestra Carta Fundamental. Así, el art. 19 de la Constitución Política (CP) dispone: «La Constitución garantiza a todas las personas: $N^{\circ}$ «El derecho a la libertad personal y a la seguridad individual». Agregando en su letra b) que «nadie puede ser privado de su libertad personal ni ésta restringida sino en los casos y en la forma determinados por la Constitución y la leyes».

${ }^{34}$ La ley $\mathrm{N}^{\circ}$ 19.789, que recientemente ha modificado el NCPP, agregó un inciso final al art. 9 disponiendo: «Tratándose de casos urgentes, en el que la inmediata autorización fuere indispensable para el éxito de la diligencia, podrá ser solicitada y otorgada por cualquier medio idóneo al efecto, tales como teléfono, fax, correo electrónico u otro, sin perjuicio de la constancia posterior». 
Por su parte, dentro del título específico dedicado a las medidas cautelares (título $\mathrm{V}$, libro I), el nuevo legislador ha establecido importantes principios generales que rigen en esta materia. Así, el art. 122 - primero del título V- recoge dos importantes principios. Dispone en el inc. $1^{\circ}$, en relación con la finalidad y alcance de estas medidas: «Las medidas cautelares personales sólo serán impuestas cuando fueren absolutamente indispensables para asegurar los fines del procedimiento y sólo durarán mientras subsistiere la necesidad de su aplicación». Agrega en el inc. $2^{\circ}$ que ellas «serán siempre decretadas por resolución judicial fundada».

En este precepto se consagran dos principios que deben guiar la labor del juez al momento de conceder una de estas medidas. En primer lugar, el principio de necesidad que nos indica que el tribunal sólo puede decretar una de estas medidas cuando ello fuese absolutamente indispensable para el cumplimiento de los fines del procedimiento. En consecuencia, bajo ningún otro respecto de conformidad con este principio puede decretarse alguna de estas medidas cautelares. Del mismo modo, nos indica este principio que las medidas acordadas sólo deben mantenerse mientras subsista la necesidad de su aplicación, debiendo cesar tan pronto como desaparezca la situación que se tuvo en vista al momento de concederla (cláusula rebus sic stantibus).

El segundo principio general que contempla el art. 122 es el de juridicidad, que es una aplicación concreta del principio básico previsto en el art. 9 antes referido. Este principio nos indica que la aplicación de estas medidas requiere siempre de una resolución judicial la cual necesariamente debe ser fundada, esto es, debe contener una justificación que permita saber por qué se ha considerado oportuno por el tribunal decretar alguna de estas medidas que, como sabemos, pueden afectar seriamente la libertad ambulatoria del imputado. No es posible, por lo tanto, que los tribunales adopten una o más de estas medidas sin justificar plenamente su procedencia, así como tampoco es procedente que un órgano no jurisdiccional como es el ministerio público pueda adoptar por sí alguna de estas medidas, requiriendo siempre de la intervención judicial como una forma de protección de los derechos fundamentales involucrados y afectados por este tipo de medidas.

Teniendo presente los principios básicos y generales que rigen en esta materia analizaremos las medidas consagradas en el articulado del NCPP.

\subsection{Medidas específicas}

El NCPP en el título V, libro I, arts. 122 y siguientes, regula específicamente cuatro tipo de medidas cautelares, a saber, la citación, la detención, la prisión preventiva, y las que denomina otras medidas cautelares, donde se recogen genéricamente siete diferentes medidas cautelares.

\subsubsection{Citación}

\subsubsection{Naturaleza}

En doctrina no se le reconoce naturaleza cautelar a la citación. Por de pronto, no es provisional en el sentido que se ha entendido la provisionalidad de las medidas cautelares. Independientemente de la llegada de otra resolución la citación es una medida que se agota en sí misma, se ordena y termina tan pronto el individuo comparece ante tribunal que expidió la orden. Por lo mismo, tampoco puede predicarse que sea 
instrumental a otra resolución principal. Adicionalmente, a través de esta medida se puede citar a terceros como son los testigos y los peritos quienes, eventualmente, pueden ser arrestados por no comparecer ${ }^{35}$. Esta última situación es completamente ajena a los fines cautelares de estas medidas. Con todo, desde una perspectiva positiva no hay duda que bajo el NCPP la citación es una de las medidas cautelares personales a las que pueden acudir los tribunales.

\subsubsection{Regulación}

En el párrafo dedicado a la citación judicial dos son los artículos que reglamentan la procedencia de esta medida, a saber, los arts. 123 y 124, este último recientemente sustituido por la ley $N^{\circ} 19.789$ publicada en el Diario Oficial el 30 de enero de 2002.

$\mathrm{El}$ art. 123, por un parte, dispone que en aquellos casos en que «fuere necesaria la presencia del imputado ante el tribunal, éste dispondrá su citación de acuerdo con lo previsto en el art. 33». El art. 123 hace referencia a la citación judicial del imputado. Ya hemos observado que a través de esta medida también se puede citar a terceros como son peritos y testigos. En este trabajo sólo nos concentraremos en la citación del imputado y no en la citación de terceros. El imputado, de acuerdo a lo previsto en el art. $7^{\circ}$, es la persona a quien se le atribuye participación en un hecho punible desde la primera actuación del procedimiento dirigido en su contra y hasta la completa ejecución de la sentencia ${ }^{36}$.

El art. 33, por su parte, señala en su inc. $1^{\circ}$ que en los casos que «fuere necesario citar a alguna persona [léase imputado en este caso] para llevar a cabo una actuación ante el tribunal, se le notificará la resolución que ordenare su comparecencia». El contenido de la citación se especifica en el inc. $2^{\circ}$ del art. 33 , debiendo indicarse el tribunal ante el cual debe comparecer, su domicilio, la fecha y hora de la audiencia, la identificación del proceso y el motivo de la citación. Asimismo, debe advertirse a la persona citada que la no comparecencia sin causa justificada dará lugar a que sea conducido por la fuerza pública, que quedará obligado al pago de las costas que se causaren y que puede imponérseles sanciones. En caso de impedimento el citado deberá comunicarlo y justificarlo ante el tribunal antes de la fecha de la audiencia, si ello fuere posible.

Ahora bien, el inc. $3^{\circ}$ del art. 33 contempla la posibilidad de que el tribunal ordene la detención o la prisión preventiva del imputado que injustificadamente no compareciere a la citación judicial. La disposición faculta al tribunal para imponer una medida cautelar más drástica en contra del imputado que sin causa justificada no acude al llamado del tribunal. En primer lugar el juez puede ordenar su detención. Esta situación se encuentra en armonía con los expresado en el inc. $2^{\circ}$ del art. 127 (norma que se ubica dentro del párrafo referido a la detención judicial): «También se decretará la detención del imputado cuya presencia en una audiencia judicial fuere condición de ésta y que, legalmente citado, no compareciere sin causa justificada». Por tanto, si el imputado ha sido citado y no

${ }^{35} \mathrm{El}$ art. 33 en su inc. $3^{\circ}$ respecto de los testigos, peritos y otras personas cuya presencia se requiera, dispone que «podrán ser arrestados hasta la realización de la actuación por un máximo de veinticuatro horas e imponérseles, además un multa de hasta quince unidades tributarias mensuales».

$36 \mathrm{El}$ inc. $2^{\circ}$ del art. $7^{\circ}$ señala que "para este efecto, se entenderá por primera actuación del procedimiento cualquiera diligencia o gestión, sea de investigación, de carácter cautelar o de otra especie, que se realizare por o ante un tribunal con competencia en lo criminal, el ministerio público o la policía, en la que se atribuyere a una persona responsabilidad en un hecho punible». 
comparece sin haber previamente justificado su inasistencia, el tribunal puede ordenar sin más trámite su detención. Es razonable que bajo estas circunstancias el juez ordene esta medida. La no comparecencia del imputado aumenta los temores de que pretenda eludir la acción de la justicia y, por tanto, el legislador autoriza al tribunal para adoptar una medida de mayor injerencia privándolo por breve tiempo de su libertad. En este evento, en todo caso, la duración máxima de la detención se encuentra expresamente regulada en el propio inc. $3^{\circ}$ del art. 33 «hasta la realización de la actuación respectiva». Por tanto, tan pronto como se realice la actividad que originó la citación el sujeto debe ser puesto en libertad.

En segundo lugar, de conformidad con el inc. $3^{\circ}$ del art. 33 el tribunal puede frente a la incomparecencia del imputado decretar la prisión preventiva del mismo. La interpretación de esta disposición puede generar más de un problema. Más adelante veremos que el tribunal puede decretar la prisión del imputado por incumplimiento de ciertas obligaciones que la ley le impone. Es una especia de sanción que prevé el legislador frente a determinadas omisiones de su parte. La situación que ahora analizamos precisamente es uno de estos casos. Por otro lado, sin embargo, para que el tribunal pueda decretar la prisión preventiva del imputado se han previstos por la ley una serie de requisitos, entre ellos, el que la medida se adopte en una audiencia en la cual la presencia del imputado y de su abogado son un requisito de validez de la actuación (inc. $3^{\circ}$ art. 142). En este caso, no obstante, la ley autoriza a decretar la prisión preventiva precisamente frente a la incomparecencia del imputado ${ }^{37}$.

En otras palabras, frente a la incomparecencia injustificada del imputado a la citación judicial el tribunal, en la audiencia respectiva ${ }^{38}$, puede directamente ordenar su prisión preventiva. En este caso, como hemos adelantado, estamos frente a una prisión preventiva que opera como una especia de sanción producto de la no comparecencia a la citación judicial, y cuya duración máxima, al igual que en el caso de la detención, se encuentra expresamente regulada en el propio inc. $3^{\circ}$ del art. 33 «hasta la realización de la actuación respectiva». Por tanto, tan pronto como se realice dicha actividad el tribunal debe ordenar el cese de la prisión preventiva.

Refuerza esta idea el inc. $3^{\circ}$ del art. 141 que, dentro del párrafo referido a la prisión preventiva, señala: «Sin perjuicio de lo anterior [situaciones en las que no procede la prisión preventiva según tendremos oportunidad de ver], el imputado deberá permanecer en el lugar del juicio hasta su término, presentarse a los actos del procedimiento y a la ejecución de la sentencia, inmediatamente que fuere requerido o citado en conformidad a los artículos 33 y 123», agregando de inmediato en el inciso siguiente: «Podrá en todo caso decretarse la prisión preventiva en los eventos previstos en el inciso segundo cuando el imputado hubiere incumplido alguna de las medidas cautelares previstas en el párrafo $6^{\circ}$ de este título, o cuando el tribunal considere que el imputado pudiere incumplir lo establecido en el inciso precedente [... la cursiva es nuestra]». Precisamente lo establecido en el «inciso precedente» - a que alude la disposición transcrita- es la

${ }^{37}$ Esto no debiera extrañarnos tanto. Si bien es cierto que es excepcional que se decrete la prisión preventiva en ausencia del imputado, ello ha sido previsto expresamente por el legislador en determinados casos. Así, por ejemplo, el inc. $4^{\circ}$ del art. 141 faculta al juez para decretar la prisión del imputado cuando éste «no hubiere asistido a la audiencia del juicio oral, resolución que se dictará en la misma audiencia a petición del fiscal o del querellante». Lo que no admite excepciones para poder ordenar la prisión preventiva es la realización de una audiencia en la cual se discuta su procedencia.

38 Recuérdese que la citación debe indicar, entre otras cosas, el tribunal ante el cual debe comparecer el imputado y la fecha y hora de la audiencia (inc. $1^{\circ} \mathrm{del}$ art. 33). 
obligación que tiene el imputado de comparecer a los actos del procedimiento y a la ejecución de la sentencia cuando fuere requerido o citado judicialmente. Como se aprecia, también en este evento, es la omisión del imputado (no comparecer a la citación del juez) la que posibilita que a su respecto se ordene directamente la prisión preventiva.

El segundo artículo que contiene el párrafo dedicado a la citación judicial como medida cautelar es el art. 124. Esta norma, como hemos observado, ha sido recientemente sustituida por el artículo único $\mathrm{N}^{\circ} 5$ de la ley $\mathrm{N}^{\circ} 19.789$. Señala el inc. $1^{\circ}$ de la nueva disposición: «Cuando la imputación se refiera a faltas, o [a] delitos que la ley no sancionare con penas privativas ni restrictivas de libertad, no se podrán ordenar medidas cautelares que recaigan sobre la libertad del imputado, con excepción de la citación» ${ }^{39}$. La norma lo que hace es excluir la prisión preventiva y cualquier otra medida cautelar personal, salvo la citación, cuando se trate de faltas, o de delitos que no llevan una sanción privativa o restrictiva de libertad. Ahora bien, el inc. $2^{\circ}$ del nuevo art. 124 nos dice que «lo dispuesto en el inciso precedente no tendrá lugar en los casos a que se refiere el inc. $4^{\circ}$ del art. $134 \mathrm{o}$ cuando procediere el arresto por falta de comparecencia, la detención o la prisión preventiva de acuerdo a lo previsto en el art. $33 »{ }^{40}$. Por tanto, después de la reforma introducida por la ley 19.789 al art. 124 debemos entender que si el imputado-citado se encuentra en alguna de las situaciones previstas en el art. 124 (faltas, o delitos que la ley no sancionare con penas privativas ni restrictivas de libertad ) y no compareciere a la citación judicial, el tribunal puede ordenar el arresto, la detención o la prisión preventiva ${ }^{41}$.

En definitiva, la citación es una medida que restringe la libertad de los sujetos por un brevísimo tiempo, y que ha sido configurada respecto de determinados delitos (faltas y delitos no sancionados con penas privativas o restrictivas de libertad) por regla general como la única medida cautelar procedente.

\subsubsection{Detención}

La detención es la privación de libertad de un sujeto por un tiempo breve y determinado con la finalidad de ponerlo a disposición del juez de garantía. Su naturaleza cautelar es reconocida por la mayor parte de la doctrina comparada aun cuando en el último tiempo han surgido algunas voces discrepantes ${ }^{42}$.

\footnotetext{
39 Se excluye del nuevo artículo 124 la referencia a las penas que no excedieren las de presidio o reclusión menores en su grado mínimo que contenía el anterior art. 124: «Cuando la imputación se refiera a faltas, o delitos que la ley no sancionare con penas privativas ni restrictivas de libertad, o bien cuando éstas no excedieren las de presidio o reclusión menores en su grado mínimo, no se podrán ordenar medidas cautelares que recaigan sobre la libertad del imputado, salvo la citación y, en su caso, el arresto por falta de comparecencia, de acuerdo con lo dispuesto en el artículo 33».

$40 \mathrm{El}$ inc. $4^{\circ}$ del art. 134 fue introducido por la aludida ley 19.789, y se refiere a situaciones en que el imputado puede ser detenido si hubiere cometido alguna de las faltas contempladas en los arts. 494 Nos. 4, 5 y 19 del Código Penal.

${ }^{41} \mathrm{La}$ interpretación es exactamente al revés de la que hacíamos con el anterior art. 124. Es deseable, en un plano de política legislativa, eliminar la facultad que el NCPP ha entregado a los jueces para ordenar la prisión preventiva del imputado cuando ha incumplido una obligación como la que ahora analizamos. Es preferible que el tribunal sólo pueda ordenar su arresto y que en presencia de su abogado se discuta el motivo de su incumplimiento y, eventualmente, la aplicación de otra medida cautelar personal. No niego que esta otra medida pueda ser incluso la prisión preventiva, pero siempre que concurran todos los requisitos y supuestos necesarios para concederla, entre ellos, sin duda los establecidos en el art. 140 que, en estas hipótesis de prisión preventiva por incumplimiento de obligaciones, no concurren.

42 Vid. BANACLOCHE, La libertad..., ob. cit., págs. 290 y ss.
} 


\subsubsection{Regulación}

La CP en el art. $19 \mathrm{~N}^{\circ} 7$ letra c) señala que «nadie puede ser arrestado o detenido sino por orden de funcionario público expresamente facultado por ley y después que dicha orden le sea intimada en forma legal. Sin embargo, podrá ser detenido el que fuere sorprendido en delito flagrante, con el sólo objeto de ser puesto a disposición del juez competente dentro de las veinticuatro horas siguientes. Si la autoridad hiciere arrestar o detener a alguna persona, deberá dentro de las 48 horas siguientes, dar aviso al juez competente, poniendo a su disposición al afectado. El juez podrá por resolución fundada, ampliar este plazo hasta por cinco días, y hasta por diez, en el caso de que se investigaren hechos calificados por la ley como conductas terroristas».

En el NCPP la detención se encuentra regulada en el párrafo $3^{\circ}$, título V, libro I, artículos 125 y siguientes, disposiciones a las que en seguida nos referiremos.

\subsubsection{Naturaleza}

La mayor parte de la doctrina comparada, como hemos avanzado, incluye a la detención dentro de la categoría de medidas cautelares. Revisemos, por tanto, de cara a la regulación legal del tema qué pasa con los presupuestos y características que en doctrina informan a las medidas cautelares.

El fumus boni iuris viene determinado, como hemos observado, por el juicio de probabilidad que se realiza acerca de la participación de un sujeto en un hecho que reviste caracteres de delito. En el nuevo orden procesal penal chileno tratándose de los casos de detención del delincuente sorprendido in fraganti, no hay duda de que la persona que practica directamente la detención (agente de policía o un particular) es quien realiza el correspondiente juicio de imputabilidad (arts. 129 y 130) ${ }^{43}$. Lo mismo se puede decir de las órdenes de detención que dicte cualquier tribunal, aun cuando no ejerza jurisdicción en lo criminal, respecto de las personas que hubieren cometido un crimen o simple delito en la sala de su despacho (art. 128).

Por el contrario, tratándose de la detención ordenada por el juez de garantía (art. 127) hubo un importante olvido del legislador nacional que no contempló elemento normativo alguno para imponer dicha medida. Recordemos que el CPP exige como fumus el que existan fundadas sospechas de participación para reputar autor, cómplice o encubridor a aquel cuya detención se ordenare ${ }^{44}$ (art. 255 CPP). Nada de esto ha sido regulado en el NCPP. Frente a esta omisión no queda sino concluir que bajo la vigencia

43 De allí que el art. 94 entre los derechos y garantías que reconoce al imputado privado de libertad, señale el derecho a que se le exprese específica y claramente el motivo de su privación de libertad (letra a). Por su parte, el art. 491 de la Ley de enjuiciamiento criminal española, en relación con la detención por un particular, señala que éste deberá justificar si el detenido lo exigiere que ha obrado en virtud de motivos racionalmente suficientes para comprender que el detenido se hallaba comprendido en algunos de los casos descritos por la ley como delito flagrante.

${ }^{44}$ En el ámbito del derecho comparado, el art. 492.4 de la Ley de enjuiciamiento criminal española señala que la «Autoridad o agente de Policía judicial tendrá obligación de detener: $4^{\circ}$. Al que estuviere en el caso del número anterior, aunque todavía no se hallase procesado, con tal que concurran las dos circunstancias siguientes: 1. ${ }^{a}$ Que la autoridad o agente tenga motivos racionalmente bastantes para creer que en la existencia de un hecho que presenta los caracteres de delito. 2. ${ }^{a}$ Que los tenga también bastante para creer que la persona a quien intente detener tuvo participación e él». 
del NCPP el ministerio público, al solicitar al juez de garantía la detención del imputado, sólo tendrá que acreditar el periculum in mora.

Este último elemento normativo, según hemos avanzado, se encuentra determinado por el riesgo de no comparecencia del imputado a la presencia judicial. Lo anterior se encuentra expresamente recogido en el inc. $1^{\circ}$ del art. 127: «Salvo los casos contemplados en el art. 124, el tribunal a solicitud del ministerio público, podrá ordenar la detención del imputado para ser conducido a su presencia, sin previa citación, cuando de otra manera la comparecencia pudiere verse demorada» (la cursiva es mía). La detención, en este caso, cumple la finalidad de aseguramiento propia de las medidas cautelares. Precisamente aquí se busca resguardar que el procedimiento transcurra dentro de los plazos previstos por el legislador, y que la actuación del imputado no lo prive de eficacia ${ }^{45}$.

Entre las características de las medidas cautelares señalamos, en primer término, el carácter provisional de las mismas, esto es, duran hasta que se dicta la resolución principal aunque pueden ser modificadas si varían las circunstancias que han determinado su adopción (cláusula rebus sic stantibus). En la regulación positiva chilena la detención es provisional porque legalmente tiene previsto un plazo máximo de duración pasado el cual, o el sujeto es puesto en libertad, o, es sometido a alguna otra medida cautelar personal (art. 131 y 132). En este sentido, la provisionalidad de la detención no lo es en los términos que hemos indicado son provisorias las medidas cautelares. Si presta atención, en este caso la detención independientemente de la llegada de otra resolución tiene preestablecido legalmente un plazo máximo de duración. La detención es —en palabras de BANACLOCHE $^{46}$ - una medida perfectamente completa «de una pieza». En este punto es donde se centra gran parte de la crítica de aquella parte de la doctrina que desconoce el carácter cautelar de la figura que estamos analizando.

La segunda característica que vimos de estas medidas es su carácter instrumental, entendida como la necesaria vinculación que existe entre la medida cautelar y la resolución principal. Esta situación, como ya se podrá vislumbrar, se ve fuertemente matizada precisamente por lo que hemos señalado en el párrafo anterior. De allí que ORTELLS si bien reconoce naturaleza cautelar a la detención -al menos respecto de algunas situaciones- siguiendo a De Luca observa que la distinción entre situaciones instrumentales y finales se apoya sobre una base esencialmente relativa por lo que la detención efectivamente no es instrumental respecto de la sentencia «porque cesa mucho antes de que ésta sea dictada; pero sí que es instrumental respecto a la prisión provisional, en cuanto asegura la posibilidad práctica de que ésta se adopte, durante el breve período de tiempo que es necesario para constatar si concurren sus presupuestos. Por tener esta característica de instrumentalidad en "segundo plano", se considera a la detención como una medida precautelar» ${ }^{47}$. Como se aprecia, la detención no nace al servicio de una providencia definitiva con el oficio de preparar el terreno y de aprontar los medios más aptos para su éxito, sino al servicio de otra medida cautelar que en el nuevo derecho chileno puede ser la prisión preventiva o alguna de las otras medidas cautelares que se

45 ORTELLS, refiriéndose a esta situación en el derecho español, observa que las medidas cautelares «están destinadas a evitar que el peligro que afecta a la práctica efectividad de una resolución judicial que — dado el orden del procedimiento- no puede adoptarse y llevarse a efecto de modo inmediato, se convierta en daño real, impidiendo que dicha resolución produzca sus efectos en la práctica o los produzca en forma menos útil que la debida». «Para una...», ob. cit., pág. 445.

${ }^{46}$ La libertad..., ob. cit. pág. 292.

47 "Para una...", ob. cit. págs. 467 y 468. 
contemplan en el art. 155 del NCPP. En Chile es perfectamente sostenible esta concepción amplia y relativa de la instrumentalidad respecto de otra medida cautelar por aplicación específica del principio de necesidad que, de conformidad con lo dispuesto en el inc. $1^{\circ}$ del art. 122, consagra una subordinación general de las medidas cautelares respecto de los fines del procedimiento, permitiendo una instrumentalidad en cascada: la detención respecto de la prisión preventiva (o de otra medida cautelar personal) y esta respecto de la sentencia definitiva.

En definitiva, desde un punto de vista doctrinal es muy discutible que la detención constituya una verdadera medida cautelar personal. Por de pronto no concurre respecto de la detención judicial el denominado fumus boni iuris, ni la provisionalidad en el sentido que hemos visto son provisionales las medidas cautelares.

\subsubsection{Casos en que procede}

Estudiaremos a continuación los distintos casos que regula el NCPP y que hacen procedente esta medida. Como premisa general el art. 125 - primero del párrafo de la detención - señala que «ninguna persona podrá ser detenida sino por orden de funcionario público expresamente facultado por ley y después que dicha orden le fuere intimada en forma legal, a menos que fuere sorprendido en delito flagrante y, en este caso, para el único objeto de ser conducido ante la autoridad que correspondiere». Como se aprecia, la norma reitera lo que sobre este particular dispone el art. $19 \mathrm{~N}^{\circ} 7$ letra c) de la C.P. Inclusive, el art. 126 garantiza en todo momento el derecho de la persona en contra de quién se hubiere expedido una orden de detención, para comparecer ante el juez de garantía y solicitar un pronunciamiento sobre su procedencia o la de cualquier otra medida cautelar.

\section{a) Detención en caso de delito flagrante ${ }^{48}$}

Dispone el inc. $1^{\circ}$ del art. 129 que «cualquier persona podrá detener a quien sorprendiere en delito flagrante, debiendo entregar inmediatamente al aprehendido a la policía, al ministerio público o a la autoridad judicial más próxima». Como se aprecia, la ley autoriza a los particulares para efectuar la detención de una persona en caso de flagrancia pero no les impone la obligación de practicarla. No es necesario que la persona que realiza la detención sea la víctima directa del delito, sino cualquier ciudadano que presencie la comisión de un ilícito. Una vez efectuada la detención el sujeto que la ha practicado tiene la obligación de conducir de inmediato al detenido a la autoridad policial, judicial o ministerial más próxima.

El inc. $2^{\circ}$ del art. 129 , por su parte, dispone que «los agentes policiales estarán obligados a detener a quienes sorprendieren in fraganti en la comisión de un delito». Por tanto, para los agentes de la policía, a diferencia de los particulares, la detención en caso de delitos flagrantes es obligatoria. La policía de conformidad con lo dispuesto por el art. 79

$48 \mathrm{El}$ art. 130 señala que se entenderá que se encuentra en situación de flagrancia: a) El que actualmente se encontrare cometiendo el delito; b) El que acabare de cometerlo; c) El que huyere del lugar de comisión del delito y fuere designado por el ofendido u otra persona como autor o cómplice; d) El que, en un tiempo inmediato a la perpetración de un delito, fuere encontrado con objetos procedentes de aquél o con señales, en sí mismo o en sus vestidos, que permitieren sospechar su participación en él, o con las armas o instrumentos que hubieren sido empleados para cometerlo, y; e) El que las personas asaltadas, heridas o víctimas de un robo o hurto que reclamaren auxilio, señalaren como autor o cómplice de un delito que acaba de cometerse. 
está integrada por Investigaciones y Carabineros de Chile. De allí que se autorice a los funcionarios de estas policías para practicar sin necesidad de recibir previamente instrucciones particulares de los fiscales, entre otras actuaciones, la detención en los casos de flagrancia conforme a la ley (art. 83 letra b).

Estas dos situaciones son las únicas que el Código autoriza para adoptar esta medida cautelar sin previa autorización judicial, siendo una excepción del principio de juridicidad que hemos previamente aludido. Lo anterior, en verdad, es de toda lógica si pensamos que en estos casos ni siquiera existe un proceso judicial en marcha ${ }^{49}$.

\section{b) Detención en caso de quebrantamiento de una condena o de una medida cautelar personal}

Dispone el art. 129 inc. final que «la policía deberá, asimismo, detener al sentenciado a penas privativas de libertad que hubiere quebrantado su condena y al que se fugare estando detenido o en prisión preventiva». Cuando la detención se produce respecto del condenado ella no reviste el carácter de una medida cautelar, sino de una medida de seguridad que busca reintegrar al condenado al estado de cumplimiento de la pena, que ya le ha sido impuesta por sentencia firme. Tratándose de la detención del sujeto que estaba detenido o sujeto a prisión preventiva lo es para conducirlo nuevamente ante el juez, el cual puede tener presente esta circunstancia como un antecedente para decretar alguna otra medida cautelar personal.

\section{c) Detención judicial}

Dispone el art. 127 que «salvo los casos contemplados en el art. 124, el tribunal a solicitud del ministerio público, podrá ordenar la detención del imputado para ser conducido a su presencia, sin previa citación, cuando de otra manera la comparecencia pudiera verse demorada o dificultada». Ya hemos criticado esta disposición por no haber configurado, a diferencia del art. 255 del CPP, algún elemento normativo de imputación en contra del sospechoso de un delito, y sólo operar con el riesgo de entorpecimiento o de demora. La historia de esta disposición no aclara si el olvido fue involuntario o si desde un momento se consideró por el legislador que no debía acreditarse este elemento. Fuere como fuere, lo cierto es que el ministerio público cada vez que tenga sospechas de que el imputado pueda entorpecer, dificultar o demorar su comparecencia frente al juez de garantía, requerirá de éste la respectiva orden de detención. En este caso el ministerio público debe explicar y acreditar los elementos en que funda su temor; entre ellos, sin duda que pueden considerarse la gravedad del delito y los antecedentes del imputado. De lo contrario sólo procede que se emplee la citación judicial.

La situación regulada en el inc. $2^{\circ}$ del art. 127 ya la vimos a propósito de la citación judicial. Son los casos de detención del sujeto que no comparece a una citación judicial y en la cual su presencia es condición de la respectiva audiencia judicial. En estos casos si el citado no comparece y no justifica previamente su ausencia, el tribunal puede ordenar sin más trámites su detención.

49 De allí que el art. 94 entre los derechos y garantías que reconoce al imputado privado de libertad, señale el derecho a que se le exprese específica y claramente el motivo de su privación de libertad y, salvo el caso de delito flagrante, a que se le exhiba la orden que la dispusiere (letra a). 


\subsubsection{Plazo de la detención}

El instante en que se inicia la detención es aquel en que la persona es inmovilizada $y$, por tanto, pierde la libertad ambulatoria en manos de la policía o del particular que la hubiere practicado. Esta situación no genera mayor inconveniente. Lo que sí puede generar algún problema es determinar hasta cuando dura esta detención. Para ello debemos distinguir entre los diversos casos que se contemplan en el NCPP. Así, tratándose de la detención en caso de delito flagrante que es practicada por un particular, el art. 129 estipula que éste debe entregar al aprehendido inmediatamente a la policía, al ministerio público o a la autoridad judicial más próxima. De aquí se concluye que bajo esta hipótesis la medida cautelar sólo dura el instante que media entre el acto mismo de la detención y su inmediata entrega a la autoridad correspondiente. Tratándose de la detención que efectúa la policía de un sujeto sorprendido in fraganti en la comisión de un hecho delictuoso, el inc. $2^{\circ}$ del art. 131 señala que el agente policial que la hubiere realizado deberá informar de ella al ministerio público dentro de un plazo máximo de doce horas. El fiscal podrá dejar sin efecto la detención u ordenar que el detenido sea conducido ante el juez dentro de un plazo máximo de veinticuatro horas, contado desde que la detención se hubiere practicado. Si el fiscal nada manifestare, la policía deberá presentar al detenido ante la autoridad judicial en el plazo indicado. En consecuencia, el plazo máximo de detención en este supuesto será de veinticuatro horas, pudiendo el fiscal en un plazo inferior dejar en libertad al sujeto.

En caso de detención judicial el agente de policía que la hubiere realizado, o el encargado del recinto de detención conducirán inmediatamente al detenido a presencia del juez que hubiere expedido la orden. Si lo anterior no fuere posible por no ser hora de despacho, el detenido podrá permanecer en el recinto policial o de detención hasta el momento de la primera audiencia judicial, por un período que en caso alguno excederá de veinticuatro horas (inc. $1^{\circ}$ del art. 131). La regla general en consecuencia es que el plazo máximo de detención sea de veinticuatro horas. Ahora bien, según veremos de inmediato el sujeto que es detenido debe ser conducido a una audiencia ante el juez de garantía. A esta audiencia debe comparecer el fiscal y allí puede solicitar la ampliación del plazo de detención hasta por tres días. El juez puede denegar o acceder a esta solicitud dependiendo de los mayores o menores fundamentos de la solicitud del fiscal. Si accede a esta petición la detención puede ser ampliada por uno, dos o tres días, decisión que queda a criterio exclusivo del juez garantía. Transcurrido el nuevo plazo de detención, cualquiera que este hubiese sido, el sujeto debe ser puesto en libertad a menos que el juez dicte en su contra la orden de prisión preventiva, u otra medida cautelar personal (art. 132). En consecuencia, en el evento de una detención judicial la regla general es que ella dure veinticuatro horas pudiendo, excepcionalmente, alcanzar un plazo máximo de cuatro días.

No se nos escapa que en esta materia no existe adecuación entre los plazos de detención que establece la CP y los que contempla el NCPP. Así, la carta fundamental establece que el juez por resolución fundada puede ampliar el plazo de detención hasta por cinco días, y hasta por diez, en el caso que se investiguen hechos calificados por ley como conductas terroristas (art. $19 \mathrm{~N}^{\circ} 7$ letra c). En principio esta situación no debiera generar mayores inconvenientes toda vez que lo que configura la $\mathrm{CP}$ es un plazo máximo de detención, lo cual no obsta a que el legislador pueda establecer un plazo inferior, que es precisamente lo que ha hecho el NCPP, quien en esta materia ha sido más garantista en el resguardo de los derechos fundamentales que el propio Constituyente. Sin embargo, decimos en "principio» porque ya se han hecho sentir algunas voces en el sentido que los 
jueces pueden ampliar el plazo de detención hasta cinco días aplicando «directamente» la Constitución.

\subsubsection{Comparecencia judicial}

Una vez que el sujeto ha sido detenido debe ser conducido en los plazos ya vistos ante el juez de garantía. De este modo, el inc. $1^{\circ}$ del art. 132 estipula que «a la primera audiencia judicial del detenido deberá concurrir el fiscal. La ausencia de éste dará lugar a la liberación del detenido». La ley, como vemos, en todo momento resguarda los derechos del imputado vigilando que estos no sean vulnerados. De allí que «presuma» que la ausencia del fiscal es indicativa de que la detención ha sido errónea, ordenando la inmediata puesta en libertad del afectado. La filosofía de la norma es clara y garantista de los derechos del imputado, aun cuando debe ponerse algún cuidado en aquellos casos en que el fiscal por motivos de fuerza mayor no pueda asistir a la referida audiencia.

En esta audiencia el fiscal procederá directamente a formalizar la investigación y a solicitar las medidas cautelares que procedieren, siempre que contare con los antecedentes necesarios y que se encontrare presente el defensor del imputado. En el evento de que no pudiere procederse de la manera indicada, el fiscal, según ya hemos adelantado, puede solicitar la ampliación del plazo de detención hasta por tres días con el fin de preparar su presentación. El juez accederá a esta petición cuando estimare que los antecedentes justifican la medida (inc. $2^{\circ}$ del art. 132). Esta norma regula principalmente aquellas situaciones en las que el proceso nace judicializado, y en las que es el fiscal no ha podido llevar adelante una investigación exhaustiva de los hechos, por ejemplo, porque el detenido ha sido sorprendido por la policía cometiendo un delito flagrante y ha sido conducido de inmediato a la presencia del juez de garantía. En estos casos sabemos que si el fiscal no concurre a la audiencia el detenido será puesto de inmediato en libertad. En estos casos el plazo de veinticuatro horas puede resultar insuficiente para que el fiscal recopile todo el material que necesita a efectos de solicitar — si así lo estima convenientealguna medida cautelar en contra del detenido. De allí que sea razonable ampliar el plazo de detención para que la fiscalía reúna la mayor cantidad de antecedentes posibles (interrogar a los policías que practicaron la detención, ubicar e interrogar a los posibles testigos del hecho, verificar en terreno la información de la policía y de los eventuales testigos, etc.) y se forme de esta manera una mejor idea de lo ocurrido. Transcurrido la ampliación del plazo (cualquiera que este hubiere sido) el fiscal deberá formalizar la investigación y requerir la aplicación de alguna medida cautelar personal en contra del detenido; en caso contrario el juez ordenará su libertad.

\subsubsection{Derechos del detenido}

El art. 135 regula lo relativo a la información que debe proporcionarse al afectado por esta medida cautelar. Así, dispone que el funcionario público encargado del procedimiento de detención deberá informar al afectado acerca del motivo de la detención al momento de practicarla. Asimismo, deberá advertirle de los derechos establecidos en el art. 93 letra a), es decir, que se le informe de manera específica y clara acerca de los hechos que se le imputaren y los derechos que le otorguen la Constitución y las leyes; letra b), esto es, que tiene derecho a ser asistido por un abogado desde los actos iniciales de la investigación; y letra g), es decir, a guardar silencio o, en caso de consentir en prestar declaración, a no hacerlo bajo juramento. Igualmente, este funcionario debe indicarle los derechos que regula el art. 94 en su letra f), esto es, que tiene derecho a entrevistarse 
privadamente con su abogado; y letra g), esto es, derecho a tener a sus expensas las comodidades y ocupaciones compatibles con la seguridad del recinto que se encontrare.

Con todo, si por las circunstancias que rodearen la detención no fuere posible proporcionar inmediatamente al detenido la información antes indicada, ella le será entregada por el encargado de la unidad policial a la cual fuere conducido. De todo ello se dejará constancia en el libro de guardia del recinto policial.

En cuanto a la forma como debe proporcionarse la información al detenido, podrá ser verbalmente o por escrito si el detenido manifestare saber leer y se encontrare en condiciones de hacerlo. La norma no contempla la posibilidad de que el detenido no entienda el idioma castellano. Lo razonable, en este evento, es que la información le sea proporcionada en presencia de un traductor ${ }^{50}$.

De acuerdo con el art. 136 es deber del fiscal, y en su caso, del juez, velar por que a los detenidos se les proporcione la información antes referida. Si comprobaren que esto no ha ocurrido, deben informar de sus derechos al detenido y remitir un oficio con los antecedentes respectivos a la autoridad competente con el objeto de que aplique las sanciones disciplinarias correspondientes o inicie las investigaciones penales que procedieren. Finalmente, el art. 137, sustituido por la ley 19.789, ordena que en todo recinto policial, de los juzgados de garantía, de los tribunales del juicio oral de lo penal, del ministerio público y de la defensoría penal pública, se exhiba, en un lugar destacado y visible claramente al público, un cartel en el cual se indiquen los derechos de las víctimas y de las personas que son detenidas. Asimismo, en todo recinto de detención policial y casa de detención deberá exhibirse un cartel en el cual se consignen los derechos de los detenidos.

\subsubsection{Prisión Preventiva}

\subsubsection{Planteamiento}

Al iniciar el estudio de la prisión preventiva debemos tener presente que es precisamente esta medida cautelar la que mayores desafíos presenta al Constituyente y al legislador al momento de establecer su regulación. Del mismo modo, representa un enorme desafío para los jueces en el día a día de su actividad. Lo anterior porque es esta medida la que constituye la injerencia más violenta del poder estatal en la esfera de libertad de los individuos, y es aquí donde con mayor énfasis se muestra la enorme tensión que existe entre la libertad de los sujetos y la necesidad de reprimir las conductas delictivas ${ }^{51}$.

${ }^{50} \mathrm{El}$ art. 291 inc. final prevé la posibilidad que el acusado no entendiere el idioma castellano, caso en el cual será asistido por un intérprete que le comunicará el contenido de los actos del juicio.

51 Para un autor como MANZINI esta dicotomía se resuelve, sin duda, a favor de la pretensión punitiva del Estado. «La pseudo democracia de tipo francés, superficial, gárrula y confusionista en todo, ha cometido también aquí el desacierto de enturbiar los conceptos, afirmando que la finalidad del proceso penal es principalmente la tutela de la inocencia [...]. Ahora bien, puesto que la finalidad del proceso penal es la de comprobar el fundamento de la pretensión punitiva del Estado en el caso concreto, y no la de hacerla a toda costa realizable, es natural que, junto a los medios encaminados a declarar la certeza de la culpabilidad, se dispongan otras para evitar el error y la arbitrariedad, y que por tal camino, junto al interés represivo, encuentre tutela en el Estado libre el interés, eventualmente en peligro, de la libertad individual. Pero como, según el orden normal de las cosas, es de presumir el fundamento de la imputabilidad y la verdad de la decisión, y no lo contrario, el interés relativo a la libertad individual representa en el proceso penal una parte sin duda esencial, pero no la más característica ni siquiera la prevalente. Una garantía no puede ponerse en el 
No sin cierta razón se ha expresado que es en la prisión preventiva donde se refleja más que en ninguna otra institución jurídica, más incluso que en la propia pena, la ideología política que subyace a un determinado ordenamiento jurídico ${ }^{52}$.

En este sentido, la realidad de los modernos Estados Constitucionales de Derecho muestra que más allá de cuestiones de índole semántica, la prisión preventiva tiene una consagración positiva y los jueces se encuentran autorizados para privar de libertad a los individuos durante la sustanciación del respectivo proceso criminal. En estos estados el principio de presunción de inocencia o de no culpabilidad se encuentra plenamente vigente. Sin embargo, por distintas razones su aplicación se encuentra mediatizada por esta medida cautelar ${ }^{53}$. De allí que resulte razonable averiguar cuáles son las razones —si es que ellas existen- que autorizan al Estado para restringir drásticamente la libertad de los individuos, sin que todavía se haya dictado una sentencia condenatoria y, por lo tanto, sin que se haya destruido el principio de presunción de inocencia o de no culpabilidad que favorece a estos individuos.

$\mathrm{Al}$ respecto nuestro estudio se va a centrar en los motivos que actualmente esgrime la doctrina comparada como justificación de la prisión preventiva, y desde esta perspectiva analizaremos la regulación positiva del tema consagrada en el NCPP. Lo anterior porque como ha puesto de relieve FERRAJOLI, «aunque en nombre de "necesidades diversas" y a veces invocando cada una como exclusiva [...] la prisión provisional acabó siendo justificada por todo el pensamiento liberal clásico» ${ }^{54}$. En definitiva, la doctrina comparada, salvo contadas excepciones ${ }^{55}$, defiende la aplicación de la prisión preventiva durante el desarrollo del proceso, y lo que ahora analizaremos es en que casos esto se ha justificado.

Sobre el particular existe relativo consenso en que los únicos fines que se aceptan en doctrina para este instituto son aquellos de carácter exclusivamente procesal. Estos son, por un lado, asegurar la presencia del imputado a la vista del juicio oral y a la ejecución de la pena; y, por el otro, evitar la alteración, destrucción o modificación de alguno de los medios de prueba que puedan usarse como prueba de cargo en el juicio oral. En Alemania

mismo plano que la función que protege. Es condición no causa, de la actividad de que se trate. Tratado..., ob. cit., págs. 252 y 253.

52 Muñoz Conde y Moreno Catena, La prisión provisional en el derecho español, Universidad Santiago de Compostela, Galicia, pág. 34.

53 En el caso del derecho español, por ejemplo, esta situación ha sido considerada posible «en virtud de los principios de proporcionalidad y excepcionalidad traducidos en la necesidad objetivamente constatable de la adopción de las medidas y en la inexistencia de otra alternativa menos gravosa para la consecución del fin apetecido [...]. ILLESCAS Rus, «Las medidas cautelares personales en el proceso penal», en Revista de derecho procesal $\mathrm{N}^{\circ} 1$ (1995), pág. 65.

54 Derecho..., ob. cit., pág. 553.

55 FERRAJOLI, por ejemplo, sostiene la ilegitimidad y la inadmisibilidad de la prisión preventiva del imputado antes de la condena para el principio de presunción de inocencia. Vid. Derecho..., ob. cit. pág. 551. Señala más adelante: «No existe, en efecto, ninguna resolución judicial y tal vez ningún acto de poder público que suscite tanto miedo e inseguridad y socave tanto la confianza en el derecho como el encarcelamiento de un ciudadano sin proceso, en ocasiones durante años. Es un mísero paralogismo decir que la cárcel preventiva no contradice el principio nulla poena sine iudicio - es decir, la jurisdiccionalidad en el sentido más lato- porque no es una pena sino otra cosa: medida cautelar, procesal o en todo caso no penal. Con parecidos fraudes de etiquetas [...] se ha disuelto - en el nuestro como en otros ordenamientos- la función de tutela del derecho penal y el papel mismo de la pena como medida punitiva exclusiva, alternativa a otras seguramente más eficaces pero no tan garantistas». Idem, págs. 555 y 556. 
ROXIN $^{56}$, refiriéndose a los fines de la prisión preventiva, señala que ella sirve para tres objetivos: pretende asegurar la presencia del imputado en el procedimiento penal; pretende garantizar una investigación de los hechos y pretende asegurar la ejecución penal. En Italia CALAMANDREI $^{57}$ refiriéndose al carácter eminentemente publicista de las medidas cautelares, observa que ello encuentra una amplia confirmación en la legislación penal, encontrándose claros y evidentes tipos de medidas dirigidas a asegurar las pruebas y el cuerpo del delito, medidas cautelares dirigidas a impedir el alejamiento del imputado, al objeto de asegurar a los fines probatorios su presencia en el proceso penal, y también a asegurar preventivamente la disponibilidad física de la persona que podrá ser objeto de ejecución penal. En España BARONA VILAR señala que «sigue siendo, sin embargo, el fin primordial de la prisión provisional el de asegurar a la persona del presunto responsable para llevar a cabo el proceso y ejecutar, en su caso, la pena o medida que se imponga» ${ }^{58}$.

Ahora bien, pese a este consenso doctrinal acerca de los fines procesales que debe cumplir esta medida, la realidad nos muestra que los diferentes ordenamientos comparados, junto con estos fines cautelares, también reconocen otros fines que alteran la naturaleza procesal de la medida conduciéndola por caminos muy diversos. Así, en el derecho alemán ROXIN observa que la Ordenanza procesal penal alemana, en su redacción original, «distinguía únicamente dos motivos de detención: sospecha de fuga y peligro de entorpecimiento. La reforma procesal penal nacional-socialista de 1935 agregó otros dos motivos que no coincidían con el fin de la prisión preventiva: peligrosidad permanente y repercusión en la opinión pública. Con ello, existía un motivo de detención cuando en virtud de la gravedad del hecho y de la repercusión provocada por él no parece tolerable dejar en libertad al acusado. La necesaria "repercusión en la opinión pública" podía ser declarada discrecionalmente por las autoridades políticas y ser manifestada por organizaciones del partido nacionalsocialista. Después de 1945 este motivo de detención fue suprimido. Luego, la ley de centralización de 1950 suprimió también el motivo de detención fundado en la peligrosidad permanente. La StPÄP [ ley para la modificación de la Ordenanza procesal penal] de 1964 -completamente en contra del fin originario establecido por la reforma, que aspiraba a la limitación de la prisión preventiva - introdujo nuevamente la peligrosidad como motivo de detención, aunque restringido a los delitos sexuales, y estableció por primera vez el motivo de detención fundado en la sospecha de asesinato» ${ }^{5}$. En Italia FERRAJOLI refiriéndose a lo que él califica como uno de los períodos más vergonzosos de la historia institucional italiana, señala que «una ley de 12 de agosto de 1982 incluyó dentro de los presupuestos de la orden de captura facultativa, junto

56 Derecho procesal penal, trad. de la 25a edición alemana de Gabriela Córdova y Daniel Pastor, Buenos Aires, 2000, pág. 257.

57 Vid. Introducción..., ob. cit., pág. 141.

58 Prisión provisional y medidas alternativas, Barcelona, 1988, pág. 20. Vid. en el mismo sentido BANACLOCHE, La libertad..., ob cit., pág. 378.

59 Derecho procesal..., ob. cit., págs. 259 y 260. Roxin critica fuertemente el peligro de reiteración como elemento para conceder la prisión preventiva. «Después de que ya en 1964 el motivo de detención de peligro de reiteración había sido introducido para determinados delitos sexuales, la ley 7/8/1972 lo hizo extensivo a numerosos delitos que, de acuerdo con la experiencia de la práctica, muchas veces son cometidos como delitos en serie, y a los que se cree poder prevenir, de modo más eficaz que hasta ahora, a través de la detención temprana del imputado. Contra un motivo de detención semejante existen varias objeciones: representa un cuerpo extraño en el sistema de los presupuestos de la detención, porque no se trata de un caso de aseguramiento del proceso, sino de una medida preventiva, por tanto, de una suerte de detención por seguridad [...]. Además, es problemático desde el punto de vista del Estado de Derecho porque aquí se impone una privación de libertad en razón de una sospecha no probada, tanto en lo que se refiere al hecho punible cometido como al hecho punible que se espera». Ídem, págs. 261y 262. 
a los peligros de fuga y alteración de las pruebas de beccariana memoria, la "peligrosidad" social del imputado en relación con las exigencias de tutela de la colectividad, que ni siquiera el Código Rocco [hace referencia al código fascista de 1930] había previsto abiertamente» $^{60}$.

Pues bien, teniendo presente los fines que en doctrina se asignan al instituto en estudio, y los diferentes caminos que en ocasiones ha seguido el legislador, veamos cuál ha sido la regulación consagrada en el NCPP.

\subsubsection{Regulación}

El art. 19 de la CP señala: «La Constitución garantiza a todas las personas: $\mathrm{N}^{\circ} 7$ «El derecho a la libertad personal y a la seguridad individual». Agregando en la letra d) del $\mathrm{N}^{\circ} 7$ : «Nadie puede ser arrestado o detenido, sujeto a prisión preventiva o preso, sino en su casa o en lugares públicos destinados a este objeto [...]». Por su parte, en la letra e) del mencionado número señala que «la libertad provisional procederá a menos que la detención o la prisión preventiva sea considerada por el juez como necesaria para las investigaciones del sumario o para la seguridad del ofendido o de la sociedad. La ley establecerá los requisitos para obtenerla».

La carta fundamental establece las condiciones generales bajo las cuales proceda la prisión preventiva y se remite al legislador para el desarrollo de los requisitos para obtener «libertad provisional». Como vemos, en esta materia tampoco existe total armonía entre las disposiciones de la Constitución y las del NCPP. Así como ya advertimos que tratándose de la detención no existe total simetría entre las disposiciones de estos dos cuerpos normativos, en el caso de la prisión preventiva las diferencias dicen relación, en primer lugar, con el concepto de «libertad provisional» que no existe en la regulación del NCPP, y, en segundo término, con las «investigaciones del sumario» de que habla la Constitución, y que el NCPP tampoco contempla. No deja de ser indicativo de la cultura autoritaria chilena que en esta materia ha imperado, el hecho de que la libertad provisional haya sido considerada por la carta fundamental como la «gran alternativa» a la prisión preventiva, no reparándose ya de entrada que su nombre constituye un gran agravio, como si la regla no fuese la libertad a secas, sin adjetivos, propia de un Estado Constitucional que respeta el principio de legalidad y el de presunción de inocencia de sus ciudadanos.

Por su parte, el NCPP regula la prisión preventiva en el párrafo $4^{\circ}$, artículos 139 y siguientes, a los cuales nos referiremos de inmediato.

\subsubsection{Significado y naturaleza}

La prisión preventiva consiste en la privación por tiempo indefinido de libertad de una persona a la que se le imputa la comisión de un delito, dirigida a asegurar en última

${ }^{60}$ Derecho..., ob. cit., pág. 554. Recordemos que el propio BECCARÍA reconocía en la prisión una especie de pena que necesariamente debía aplicarse antes que la declaración del delito, y cuyo fundamento excedía los estrictamente cautelares: «La prisión es una pena que por necesidad debe, a diferencia de las demás, preceder a la declaración del delito, pero este carácter distintivo suyo no le quita otro esencial, esto es, que sólo la ley determina los casos en que el hombre es digno de esta pena. La ley pues señalará los indicios de un delito que merezcan la prisión de un reo, que lo sujeten al examen y a la pena. La fama pública, la fuga, la confesión extrajudicial, la de un compañero en el delito, las amenazas y constante enemistad con el ofendido, el cuerpo del delito y otros semejantes, son pruebas suficientes para encarcelar a un ciudadano». De los delitos y de las penas, facsimilar de la edición príncipe en italiano de 1764, seguida de la traducción de Juan Antonio de las Casas de 1774, México, 2000, pág. 284. 
instancia la efectividad de la eventual sentencia condenatoria con que pueda finalizar el proceso penal.

Su naturaleza, como hemos adelantado, va a depender de cuál sea la finalidad que se considere prioritaria por el legislador nacional. Más allá de lo señalado expresamente en el art. 150 inc. $3^{\circ}$ en cuanto a que el imputado «será tratado en todo momento como inocente. La prisión preventiva se cumplirá de manera tal que no adquiera las características de una pena, ni provoque otras limitaciones que las necesarias para evitar la fuga y para garantizar la seguridad de los demás internos y de las personas que cumplieren funciones o por cualquier motivo se encontraren en el recinto», lo cierto es que debemos analizar qué fines se han consagrado en el nuevo texto legal. Si ellos son exclusivamente procesales, como parece darlo a entender este artículo ni provoque otras limitaciones que las necesarias para evitar la fuga, entonces la prisión tendrá la naturaleza de una verdadera medida cautelar personal. Si, por el contrario, el legislador ha avanzado hacia otros derroteros puede, incluso, llegar a ser considerada como una pena anticipada, censurable desde todo punto de vista.

Por de pronto, la duración indefinida de la prisión preventiva es uno de los aspectos más criticables de esta institución. De hecho, el proyecto original del ejecutivo contemplaba una duración máxima de 18 meses ${ }^{61}$. La modificación de esta situación se realizó por la Cámara de Diputados que en una argumentación insólita consideró que «el establecimiento de la disposición era un error, o por cuanto, en la práctica conduce a que el juez tenga a la persona privada de libertad por dieciocho meses $[\dot{i} ?])^{62}$.

Ahora bien, dejando a un lado las extravagancias de nuestro legislador analicemos, de cara a la regulación positiva del tema, cuál es la naturaleza que se ha reconocido por el NCPP a esta institución.

\subsubsection{Principios}

Diversos son los artículos que regulan la prisión preventiva al interior del NCPP, los cuales iremos interpretando armónicamente a efectos de situar en su justo cauce la aplicación de esta medida cautelar. Dentro de los principios que informan la nueva legislación ya hemos visto los principios básicos y los principios generales aplicables en esta materia. En esta ocasión corresponde analizar los principios específicos de la prisión preventiva. En este sentido, el artículo 139 inc. $2^{\circ}$ contiene una disposición clave en este ámbito: «La prisión preventiva sólo procederá cuando las demás medidas cautelares personales fueren insuficientes para asegurar las finalidades del procedimiento».

Es decir en materia de medidas cautelares personales la prisión preventiva debe tener una aplicación subsidiaria. Debe ser la ultima ratio en esta materia. Sólo en el evento que no tenga aplicación alguna de las otras medidas cautelares personales que consagra el

${ }^{61} \mathrm{El}$ art. 183 del mensaje bajo el título Límites temporales establecía en el inc. $2^{\circ}$ que: «El juez estará asimismo obligado a ordenar la cesación de la prisión preventiva cuando su duración alcanzare la mitad de la pena privativa de libertad que se pudiere esperar en el evento de dictarse sentencia condenatoria o [de] la que se hubiere impuesto existiendo recursos pendientes. La prisión preventiva no podrá exceder en caso alguno de dieciocho meses, a menos que se bubiere dictado sentencia condenatoria». (La cursiva es mía).

$621 \mathrm{er}$. Informe de la Comisión de constitución, legislación y justicia, párrafo referente al art. 181. En un plano de política legislativa sería deseable limitar temporalmente la duración de esta medida, y reestablecer la idea original del ejecutivo aunque con un plazo inferior. 
NCPP, puede el juez decretar la prisión preventiva del imputado en la medida, obviamente, que a su respecto se cumplan los demás requisitos que autorizan su procedencia.

En segundo lugar, en esta materia no sólo rige el principio de subsidiaridad que acabamos de ver, sino que también rige el principio de proporcionalidad ${ }^{63}$, recogido expresamente en el artículo 141 del NCPP. En su inciso primero consagra lo que constituye una norma de general aplicación: No se podrá ordenar la prisión preventiva cuando ésta aparezca desproporcionada en relación con la gravedad del delito, las circunstancias de su comisión y la sanción probable. Es decir, el legislador procesal sitúa la prisión preventiva en estricta relación con su carácter de medida cautelar personal y, por lo tanto, si el delito no reviste mayor gravedad y la sanción probable asignada, de acuerdo con las particularidades circunstancias de su comisión, no hacen presumir que el imputado buscará eludir las fines de la medida — evitar el riesgo de fuga y destrucción de medios de prueba— entonces ella no debe decretarse.

Fuera de esta regla general, en el inc. $2^{\circ}$ del artículo que estamos analizando se contemplan dos situaciones concretas de aplicación de este principio (letras a y b) en las que no cabe la prisión preventiva —a menos que hubiere algún tipo de incumplimiento por parte del imputado según veremos al analizar el inc. $4^{\circ}$ del mismo artículo- y una tercera situación (letra c) que deja al criterio del tribunal la procedencia de la medida, en relación con algunos requisitos que deben acreditarse ante él. Así, dispone categóricamente este inc. $2^{\circ}:$ «No procederá la prisión preventiva:

a) Cuando el delito imputado estuviere sancionado únicamente con penas pecuniarias o privativas de derechos, o con una pena privativa o restrictiva de libertad de duración no superior a la de presidio o reclusión menores en su grado minimo. Resulta lógico que si la pena máxima que se prevé para un determinado delito no contempla la posibilidad de que el sujeto quede privado de libertad, no proceda a su respecto la prisión preventiva, que en este caso, resultaría del todo desproporcionada a los fines cautelares que ella persigue. En relación con aquellos delitos cuya pena privativa o restrictiva de libertad no es superior a la de presidio o reclusión menor en su grado mínimo, se pone una vez más de manifiesto que el legislador entiende que el imputado no intentará eludir la acción de la justicia, y por ello no contempla la prisión preventiva como medida que limite su libertad.

b) Cuando se trate de un delito de acción privada. Recordemos que los delitos de acción privada son aquellos en que la acción sólo puede ser ejercida por la víctima (art. 53 inc. 3), y que se encuentran establecidos en el art. 55. En general la razón para que en esta clase de ilícitos no proceda la prisión preventiva es similar a la contemplada en la letra a) precedente. Son delitos cuya pena máxima no es grave por lo que se parte de la base que el imputado no tendrá mayor interés en dificultar el accionar del proceso y de la justicia, siendo desproporcionado, en este caso, aplicar una medida como la prisión preventiva.

\footnotetext{
63 Este principio surge en el marco de la jurisprudencia constitucional alemana como un mecanismo de control de constitucionalidad de la actuación de los poderes públicos en la limitación de los derechos fundamentales, tanto en relación con la creación normativa como en la aplicación del Derecho. Vid. KLUTH, «Prohibición de exceso y principio de proporcionalidad en [el] Derecho Alemán», en Cuadernos de derecho público, Madrid, N 5, sep-dic. (1998), págs. 219-237.
} 
c) Cuando el tribunal considere que, en caso de ser condenado, el imputado pudiere ser objeto de alguna de las medidas alternativas a la privación o restricción de libertad contempladas en la ley y éste acreditare tener vínculos permanentes con la comunidad, que den cuenta de su arraigo familiar o social. En este caso el tribunal debe realizar un análisis y determinar la eventual aplicación de alguna de las medidas alternativas a la privación de libertad que se contemplan en la ley 18.216 (remisión condicional de la pena, reclusión nocturna y libertad vigilada) para el caso de que el imputado sea finalmente condenado. Adicionalmente, se debe acreditar ante el tribunal que el imputado tiene una vinculación permanente con la comunidad, que hagan presumir, una vez más, que el sujeto en cuestión no tratará de fugarse. En caso de que efectivamente la posible sentencia condenatoria admita la aplicación de alguna medida alternativa, y el imputado acredite tener vínculos sociales permanentes (familia, trabajo, buena reputación, entre otros) entonces no procede que en su contra se dicte la prisión preventiva que en este evento resultaría desproporcionada a los fines que la medida persigue.

En estas tres hipótesis el imputado debe permanecer en el lugar donde se desarrolla el juicio hasta su término, debiendo presentarse a todos los actos de procedimiento y a la ejecución de la sentencia inmediatamente que fuere requerido o citado en conformidad a los arts. 33 y 123 (inc. $3^{\circ}$ art. 141).

Excepciones al principio de proporcionalidad: En el inc. $4^{\circ}$ del art. 141 se contemplan tres situaciones que hacen procedente la prisión preventiva respecto de las hipótesis previstas en las letras a), b) y c) precedentes. En relación con las dos primeras situaciones (letras a y b) recordemos que algo ya hemos avanzado al tratar la citación judicial. Al respecto dispone el mencionado inc. $4^{\circ}$ : «Podrá en todo caso decretarse la prisión preventiva en los eventos previstos en el inciso segundo cuando el imputado hubiere incumplido alguna de las medidas cautelares previstas en el párrafo $6^{\circ}$ de este Título, o cuando el tribunal considere que el imputado pudiere incumplir lo establecido en el inciso precedente $[. ..] \gg$. Luego veremos que en el párrafo $6^{\circ}$ aludido se contemplan las denominadas otras medidas cautelares que limitan la libertad del imputado durante el transcurso del proceso de manera menos severa que la prisión preventiva. De allí que si el imputado quebranta alguna de estas otras medidas el tribunal pueda decretar en su contra una medida más drástica como es la prisión preventiva. En la segunda hipótesis, en cambio, para que se pueda decretar esta última medida deben existir elementos serios y fundados que lleven al tribunal a concluir que el imputado se ausentará del lugar donde se desarrolla el juicio, no presentarse a algún acto de procedimiento o a la ejecución de la pena (por ejemplo, venta de todas sus propiedades, renuncia a su trabajo, viaje al extranjero). Situaciones, en el fondo, que muestren seriamente que el sujeto incumplirá lo ordenado en el inc. $3^{\circ}$ del art. $141 \mathrm{y}$, por tanto, que es procedente la prisión preventiva.

En relación con la tercera situación que hace procedente esta medida cautelar, dispone la parte final del inc. $4^{\circ}$ del art. 141: «[...]. Se decretará también la prisión preventiva del imputado que no hubiere asistido a la audiencia del juicio oral, resolución que se dictará en al misma audiencia a petición del fiscal o del querellante. Como vemos en este evento el peligro de que el sujeto no comparezca a la audiencia del juicio oral (hipótesis que se comprende dentro de la obligación genérica que tiene el imputado de presentarse a los actos de procedimiento) ya ha ocurrido, y por ello el legislador autoriza para que en su ausencia se decrete, a petición del fiscal o del querellante, inmediatamente la prisión preventiva. 
En todas estas hipótesis, que constituyen una excepción al principio de proporcionalidad, la prisión preventiva opera como una especie de sanción frente a ciertas omisiones del imputado en relación con determinadas obligaciones que la ley le ha impuesto. En todos estos casos el elemento que posibilita la aplicación de esta medida no es ninguno de los elementos que positivamente consagra el legislador para decretar la prisión preventiva como medida cautelar, sino, un claro incumplimiento o amenaza de él por parte del imputado.

\subsubsection{Presupuestos de aplicación}

\section{a) Presupuestos objetivos}

El artículo 140 del NCPP señala que «una vez formalizada la investigación, el tribunal, a petición del ministerio público o del querellante, podrá decretar la prisión preventiva del imputado siempre que el solicitante acredite que se cumplen los siguientes requisitos:

a) Que existen antecedentes que justificaren la existencia del delito que se investigare;

b) Que existen antecedentes que permitieren presumir fundadamente que el imputado ha tenido participación en el delito como autor, cómplice o encubridor, y

c) Que existen antecedentes calificados que permitieren al tribunal considerar que la prisión preventiva es indispensable para el éxito de las diligencias precisas y determinadas de la investigación, o que la libertad del imputado es peligrosa para la seguridad de la sociedad o del ofendido».

Como se aprecia, en cuanto a los presupuestos objetivos de concesión de la medida tenemos en primer lugar nuestro conocido fumus boni iuris, que se encuentra recogido en las presunciones fundadas de participación y en los antecedentes que justifiquen la existencia del delito que se investiga (letras a y b precedentes). No cabe duda, en consecuencia, que respecto de este elemento existe una configuración normativa que encuadra perfectamente con lo afirmado por la doctrina sobre este particular.

El periculum in mora se configura, como sabemos, por el peligro de que en definitiva el imputado no comparezca al proceso y por el peligro de alteración, destrucción o modificación de los medios de prueba. Es aquí donde debemos analizar con detención las finalidades que el legislador ha atribuido a esta medida en la letra c) precedente.

c1) Que existan antecedentes calificados que permitieren al tribunal considerar que la prisión preventiva es indispensable para el éxito de las diligencias precisas y determinadas de la investigación. Esta situación parece encuadrar sin mayores problemas en uno de los fines procesales que la doctrina reconoce a esta medida. Reafirma esta situación el contenido que el legislador le dio a este criterio en el inc. 2 del art. 140: «Se entenderá que la prisión preventiva es indispensable para el éxito de la investigación cuando existiere sospecha grave o fundada de que el imputado pudiere obstaculizar la investigación mediante la destrucción, modificación, ocultación o falsificación de elementos de prueba; o cuando pudiere inducir a coimputados, testigos, peritos o terceros para que informen falsamente o se comporten desleal o reticente». Como se aprecia la norma es imperativa: Se entenderá que la prisión preventiva es indispensable... Así, bajo el NCPP la prisión preventiva tiene como finalidad evitar que el imputado intente obstaculizar la investigación, ya sea mediante la destrucción, 
alteración, ocultación o falsificación de pruebas de cargo, o a través de la inducción de otras personas a que informen falsamente, no colaboren, o tengan un comportamiento desleal con la investigación. La sospecha en este caso debe ser grave y fundada. No basta, por lo tanto, con una mera suposición del fiscal, sino que debe acreditar ante el tribunal la gravedad y fundamento de su sospecha. Debe demostrar por qué motivo cree que el imputado va a obstaculizar la investigación y la manera como ello podría ocurrir. Ahora bien, una vez que este peligro ha desaparecido, por ejemplo, porque el fiscal ya ha reunido el material probatorio y no hay posibilidades de alterarlo, destruirlo, ocultarlo o falsificarlo, o porque el imputado ha confesado y no hay posibilidad de inducir a coimputados, testigos, peritos o terceros para falsear o alterar las pruebas, nada justificaría la continuidad de la medida.

c2) Que la libertad del imputado sea peligrosa para la seguridad de la sociedad. El concepto de peligrosidad social, como ya hemos visto, ha sido enérgicamente rechazado por la doctrina comparada como posible fin de esta medida. Este criterio aisladamente considerado es desde todo punto de vista censurable como elemento para negar la libertad del imputado. Con todo, al explicitar el legislador en el inc. $3^{\circ}$ del art. 140 el contenido de la peligrosidad para la sociedad aparecen elementos que atenúan nuestra crítica. Señala el aludido inciso: Para estimar si la libertad del imputado resulta o no peligrosa para la seguridad de la sociedad, el tribunal deberá considerar especialmente alguna de las siguientes circunstancias: la gravedad de la pena asignada al delito; el número de delitos que se le imputare y el carácter de los mismos; la existencia de procesos pendientes; el hecho de encontrarse sujeto a una medida cautelar personal, en libertad condicional o gozando de alguno de los beneficios alternativos a la ejecución de las penas privativas o restrictivas de libertad contempladas en la ley; la existencia de condenas anteriores cuyo cumplimiento se encontrare pendiente, atendiendo a la gravedad de los delitos de que se trataren, y el hecho de haber actuado en grupo o pandilla. Creo que este elemento puede ser reconducido a los fines cautelares que la doctrina señala debe cumplir esta institución. Así, lo que busca el legislador al explicitar en este inciso los motivos que especialmente debe tener presente el juez al considerar si la libertad del imputado es peligrosa para la seguridad de la sociedad, no es otro que poner de manifiesto el peligro de que en definitiva el imputado no comparezca al juicio y, en su día, a la aplicación de la eventual pena. Así, las situaciones descritas en el inc. $3^{\circ}$ del art. 140 van desde la gravedad de la pena asignada al delito (entendiendo que a mayor gravedad hay mayor riesgo de fuga y, por tanto, mayor posibilidad que se aplique la medida); del número y carácter de los delitos; de los antecedentes del imputado (existencia de condenas anteriores, de procesos pendientes, de otras medida cautelares, etc.) hasta las circunstancias mismas del hecho delictivo que revelan una peligrosidad especial del imputado (haber actuado en grupo o pandilla). Son todos elementos que de una u otra forma dan a entender un especial peligro de no comparecencia del imputado al juicio penal ${ }^{64}$.

c3) Que la libertad del imputado sea peligrosa para la seguridad del ofendido. Este tercer criterio se aleja de los fines cautelares que se reconoce a la prisión preventiva. En efecto, dispone el inc. $4^{\circ}$ del art. 140 que «se entenderá que la seguridad del ofendido se encuentra en peligro

${ }^{64}$ Como se comprenderá, en todo caso, la situación es muy discutible. No desconozco que estos mismos elementos pueden llevar a interpretar la disposición en el sentido de que lo que se desea evitar en la reincidencia del imputado y, por tanto, lo que habría sería una presunción de peligrosidad basada en la gravedad del delito, en los antecedentes del imputado, en las circunstancias de la comisión del hecho, etc. Todos estos antecedentes lo que en verdad mostrarían es que el sujeto es peligroso para la seguridad de la sociedad no porque se tema su fuga, sino porque, principalmente, se teme que vuelva a cometer nuevos delitos. Creo, en todo caso, que el diseño de la prisión preventiva bajo el NCPP nos permite establecer una interpretación más garantista de este criterio. 
por la libertad del imputado cuando existieren antecedentes calificados que permiten presumir que éste realizará atentados graves en contra de aquél, o en contra de su familia o bienes». Al respecto FERRAJOLI ha observado que «la perversión más grave del instituto, legitimada desgraciadamente por Carrara y antes por Pagano, ha sido su transformación de instrumento exclusivamente procesal, dirigido a "estrictas necesidades" sumariales, en instrumento de prevención y de defensa social, motivado por la necesidad de impedir al imputado la ejecución de otros delitos». Si analizamos con detención en este caso lo que existe es una presunción de peligrosidad basada únicamente en la sospecha de que el sujeto puede cometer nuevos delitos en contra de la víctima, su familia o sus bienes. Lo que equivale de hecho «a una presunción de culpabilidad; y al asignar a la custodia preventiva los mismos fines, además del mismo contenido aflictivo que la pena, le priva de esa especie de hoja de parra que es el sofisma conforme al cual sería una medida "procesal", o "cautelar", y en consecuencia, "no penal", en lugar de una ilegítima pena sin juicio» 65 .

En esta parte quedó de manifiesto la dos corrientes que concurrieron en la elaboración del NCPP. En definitiva, como no se modificó la norma constitucional que regula la libertad provisional resultó difícil, en el plano legislativo, modificar los elementos consagrados en la Constitución y se optó por reproducirlos.

Pero esta situación final no debe hacernos olvidar que el NCPP es mucho más garantista que la anterior legislación que regía esta materia, y que es a la luz de todas sus disposiciones que debemos interpretar la procedencia o no de la prisión preventiva. Por de pronto, no olvidemos que ella es la última de las medidas cautelares personales a las que se puede acudir para restringir los derechos de los ciudadanos (principio de subsidiaridad). Y no olvidemos, tampoco, que en esta materia hay un importante avance en relación con la normativa del CPP, ya que bajo la nueva legislación no existe la prisión automática como sí ocurre bajo el viejo procedimiento penal, en el cual al dictarse la resolución que somete a proceso la detención se convierte mecánicamente en prisión preventiva (art. 277 del CPP). Nada de ello ocurre en el NCPP que requiere siempre para decretar esta medida de una resolución judicial que expresa y fundadamente señale por qué motivo se ha adoptado la medida en cuestión.

En definitiva, se puede apreciar que la mayoría de los criterios que se contemplan para decretar la prisión preventiva coinciden con los fines procesales que la doctrina reconoce a esta institución. Si bien, el concepto de peligro para la seguridad del ofendido se aleja de esta situación, ello se ve moderado por la inmediata aplicación de una serie de principios que rigen en esta materia, y particularmente, por la aplicación de los principios de excepcionalidad y de proporcionalidad que son clave a la hora de determinar la aplicación de esta medida cautelar.

\section{b) Presupuestos subjetivos}

Sabemos que en conformidad con el artículo 122 inc. $2^{\circ}$ estas medidas deben siempre decretarse por medio de resolución judicial fundada. El art. 143 dispone que al concluir la audiencia el tribunal se pronunciará sobre la prisión preventiva por medio de

${ }^{65}$ Ferrajoli, Derecho..., ob. cit., pág. 553. En España Ortells afirma que «al basarse exclusivamente en un juicio de probabilidad sobre la responsabilidad penal del imputado, supone dar a este un trato de condenado, previamente a la sentencia irrevocable de condena». «Para una...», ob. cit., pág. 459. 
una resolución fundada, en la cual expresará claramente los antecedentes calificados que justifican la decisión. Por su parte el artículo 154, dentro de los requisitos comunes a la prisión preventiva y la detención, nos dice que toda orden de prisión preventiva y de detención será expedida por escrito por el tribunal, y contendrá: a) el nombre y apellidos de la persona que debiere ser detenida o aprehendida o, en su defecto, las circunstancias que la individualizaren o determinaren; b) el motivo de la detención o prisión; y c) la indicación de ser conducido de inmediato ante el tribunal, al establecimiento penitenciario o lugar público de prisión o detención que determinare, o de permanecer en su residencia según correspondiere (la cursiva es mía). En consecuencia, la prisión preventiva es una medida exclusivamente judicial, que debe siempre explicitar los motivos que ha tenido presente el tribunal para ordenarla.

Esta medida, en principio, sólo puede ser ordenada por el juez de garantía competente. Dispone a este respecto el art. 70 inc. $1^{\circ}$ que «el juez de garantía llamado por la ley a conocer las gestiones a que dé lugar el respectivo procedimiento se pronunciará sobre las autorizaciones judiciales previas que solicitare el ministerio público para realizar actuaciones que privaren, restringieren o perturbaren el ejercicio de derechos asegurados por la Constitución». Es con este mismo tribunal que deben entenderse las diligencias relativas a la ejecución de la medida. Dispone a este respecto el art. 150 en su inc. $1^{\circ}$ que «el tribunal será competente para supervisar la ejecución de la prisión preventiva que ordenare en las causas de que conociere. A él corresponderá conocer de las solicitudes y presentaciones realizadas con ocasión de la ejecución de la medida».

Con todo, la ley permite que en los casos en que la actuación judicial debiera efectuarse fuera del territorio jurisdiccional del juzgado de garantía competente, y se tratare de diligencias urgentes, el ministerio público también podrá pedir la autorización directamente al juez del juzgado de garantía del lugar. En este caso, una vez realizada la diligencia, el ministerio público dará cuenta a la brevedad al juez de garantía del procedimiento. Igualmente, en caso de conflicto de competencia la medida debe adoptarla el juez en cuyo territorio jurisdiccional se encontraren los imputados (art. 72). Dirimido el conflicto de competencia las personas que se encontraren privadas de libertad, así como los antecedentes que obraren en poder de los demás jueces que hubieren intervenido, serán puestos inmediatamente a disposición del juez competente. Todas las actuaciones practicadas ante los jueces incompetentes serán válidas sin necesidad de ratificación (art. 73). Del mismo modo, la ley permite que el juez que estuviere subrogando al juez de garantía inhabilitado continúe conociendo de todos los trámites anteriores a la preparación de la audiencia del juicio oral, entre ellos, por cierto, la solicitud de una medida cautelar como la prisión preventiva (art. 75).

Excepcionalmente el NCPP faculta al tribunal del juicio oral en lo penal para ordenar esta medida. Así se desprende del inc. 2 del art. 142 que nos dice que la prisión preventiva puede solicitarse verbalmente en la audiencia de formalización de la investigación, en la audiencia de preparación del juicio oral, o en la audiencia del juicio oral. Esta última audiencia se realiza precisamente ante el tribunal colegiado encargado de conocer el juicio mencionado. En otras palabras, durante el juicio oral le corresponde decretar la prisión preventiva al órgano jurisdiccional que conoce del respectivo juicio.

La regla general es que el juez para poder adoptarla debe actuar a petición de parte. Quienes deben solicitar la aplicación de esta medida son el ministerio público y el querellante, si lo hubiere. Son ellos quienes deben pedir la tribunal que decrete la prisión 
preventiva. Así lo señala expresamente el art. 140. Con todo, el art. 144 reconoce cierta facultad al juez para decretar de oficio esta medida. A ello nos referiremos más adelante.

Finalmente, la medida sólo puede ser decretada en una audiencia en la que el juez debe resolver sobre la respectiva petición $\mathrm{Al}$ respecto dispone el inc. $3^{\circ}$ del art. 142 que «la presencia del imputado y su defensor constituye un requisito de validez de la audiencia en que se resolviere la solicitud de prisión preventiva"». Como hemos adelantado, la celebración de esta audiencia es un requisito de la esencia para adoptar la prisión preventiva que no admite excepciones.

\subsubsection{Procedimiento de adopción de la prisión preventiva}

La solicitud de prisión preventiva puede plantearse verbalmente en cualquiera de las siguientes audiencias:

1. En la de formalización de la investigación: En conformidad con el art. 299 la formalización de la investigación es la comunicación que el fiscal efectúa al imputado, en presencia del juez de garantía, de que desarrolla actualmente una investigación en su contra respecto de uno o más delitos determinados. El fiscal puede formalizar la investigación cuando lo estimare oportuno, pero debe necesariamente hacerlo cuando solicite al juez de garantía alguna medida cautelar como es la prisión preventiva (art. 230).

Si el sujeto hubiere sido detenido y conducido a la presencia judicial, el fiscal debe comparecer a esa primera audiencia y proceder directamente a formalizar la investigación. En dicha audiencia debe solicitar las medidas cautelares que estime procedentes, entre ellas, la prisión preventiva (art. 132). Si el sujeto no estuviere en el caso anterior, el fiscal debe solicitar al juez de garantía la realización de una audiencia en fecha próxima, mencionando la individualización del imputado, la indicación del delito que se le atribuyere, la fecha y lugar de su comisión y el grado de participación del imputado en el mismo. A esta audiencia se citará al imputado, a su defensor y a los demás intervinientes en el procedimiento (art. 231).

En la audiencia de formalización el juez ofrecerá la palabra al fiscal para que exponga verbalmente los cargos que presentare en contra del imputado y las solicitudes que efectuare al tribunal. Es precisamente en este momento en que el fiscal debe requerir la prisión preventiva del imputado señalando, con toda precisión, los motivos por los cuales en su opinión es procedente esta medida. Seguidamente el imputado podrá manifestar lo que estimare conveniente. Este es el instante en el cual su abogado debe exponer los argumentos por los cuales no es procedente la prisión preventiva, por ejemplo, porque no concurren ninguno de los elementos para decretarla, o porque con la medida se vulnera el principio de proporcionalidad o de excepcionalidad que hemos visto rigen en esta materia (art. 232)

2. En la audiencia de preparación del juicio oral. El art. 260 nos indica que presentada la acusación el juez de garantía ordenará su notificación a todos los intervinientes y citará, dentro de las veinticuatro horas siguientes a la audiencia de preparación del juicio oral, la que deberá tener lugar en un plazo no inferior a veinticinco ni superior a treinta y cinco días. Por su parte, el art. 266, en relación con el desarrollo de esta audiencia, nos dice que ella será dirigida por el juez de garantía, quién la presenciará 
en su integridad, se desarrollará verbalmente y durante su realización no se admitirá la presentación de escritos. Por lo tanto, junto con resolver los trámites propios de esta audiencia (excepciones de previo y especial pronunciamiento, si las hubiere, debate acerca de las pruebas ofrecidas, conciliación sobre las acciones civiles, etc.) verbalmente el fiscal puede solicitar la prisión preventiva del imputado, justificando su procedencia. La defensa, por su parte, pedirá que se deseche tal solicitud.

3. En la audiencia del juicio oral. Nos señala el art. 282 que la audiencia del juicio oral se desarrollará en forma continua y podrá prolongarse en sesiones sucesivas hasta su conclusión. Por su parte, el art. 284 nos dice que la audiencia del juicio oral se realizará con la presencia ininterrumpida de los jueces que integran el tribunal y del fiscal. La audiencia se desarrollará en forma oral, tanto en lo relativo a las alegaciones y argumentaciones de las partes, como a las declaraciones del acusado, a la recepción de las pruebas y, en general, a toda intervención de quienes participan en ella (art. 291). En este caso, la solicitud del fiscal se realizará ante un tribunal colegiado quien es el tribunal competente para resolver sobre esta petición. No olvidemos que en caso de ausencia del imputado a esta audiencia, el tribunal puede previa petición de parte, decretar de inmediato su prisión preventiva.

4. En una audiencia citada especialmente al efecto. Finalmente, como es lógico, la prisión preventiva puede pedirse en cualquier etapa de la investigación, respecto del imputado contra quien se hubiere formalizado ésta. En este caso, el juez debe fijar una audiencia para la resolución de la solicitud, citando al imputado, a su defensor y a los demás intervinientes. (art. 142 inc. $2^{\circ}$ ).

Compareciendo las partes en la fecha y hora fijadas por el juez se procederá a celebrar la audiencia respectiva ${ }^{66}$. En general, ya sea que el tribunal hubiere citado a una audiencia especial para resolver la petición del fiscal, o que tal petición se hubiere planteada verbalmente en alguna de las tres audiencias mencionadas con anterioridad, el desarrollo de estas, en relación con la solicitud de prisión preventiva, es el siguiente:

a) Alegaciones de las partes: En la respectiva audiencia el fiscal debe ratificar su petición sobre prisión preventiva (en el caso de una audiencia especialmente citada al efecto), o pedir verbalmente su aplicación (en las demás audiencias). En seguida, el tribunal debe ofrecer la palabra al defensor y a los demás intervinientes que estuvieren presentes y quisieren hacer uso de la palabra. Al respecto, el art. 142 en su inciso final nos dice que «una vez expuestos los fundamentos de la solicitud por quién la hubiere formulado, el tribunal oirá en todo caso al defensor, a los demás intervinientes si estuvieren presentes y quisieren hacer uso de la palabra y al imputado.

b) Proposición de prueba: No olvidemos que la resolución que se pronuncia sobre la prisión preventiva debe ser fundada. En ella el juez debe expresar claramente los

66 Puede ocurrir que el día señalado la audiencia no se realice. Ello puede suceder cuando no concurra algunos de los sujetos que necesariamente debe asistir a su celebración. La ausencia del juez no está prevista como causal de no celebración de la audiencia, pero es obvio que sin su presencia la audiencia no puede llevarse a efecto. Habrá que señalar un nuevo día y hora para tal efecto. Si no comparece el fiscal y el imputado se encuentra detenido se decretará de inmediato su libertad. Si no comparece el abogado defensor, se produce abandono de la defensa y el juez procederá a nombrar un abogado de oficio. Si no comparece el imputado, sabemos que en este evento, de acuerdo con la modificación introducida por la ley 19.789, el tribunal puede ordenar su arresto, detención o prisión preventiva (art. 33 inc. $3^{\circ}$ en relación con el inc. $2^{\circ}$ del art. 124). 
antecedentes calificados que justificaren su decisión (art. 143). De allí que el solicitante de la medida no sólo debe indicar los fundamentos de su pretensión sino que, en aquellos casos que fuere necesario, adjuntar los elementos que sustenten su petición. Esto último ocurrirá principalmente en aquellas situaciones en que se cite a una audiencia especial para resolver sobre la petición del fiscal.

c) Decisión del juzgador: Finalmente, la solicitud de prisión preventiva, cualquiera hubiere sido la audiencia en que hubiese sido formulada, debe ser resuelta por el tribunal. Al respecto, el art. 143 nos señala que «al concluir la audiencia el tribunal se pronunciará sobre la prisión preventiva por medio de una resolución fundada, en la cual expresará claramente los antecedentes calificados que justificaren la decisión». Es decir, el tribunal debe expresar palmariamente por qué razón estima que es procedente o improcedente la medida solicitada. Esta es la única forma de controlar que la decisión del juez sea efectivamente motivada y que se ajuste los principios subsidiaridad y proporcionalidad que rigen en esta materia. Asimismo, es la manera de evitar resoluciones arbitrarias o ajenas a las alegaciones de las partes. Sobre este particular el art. 36 nos dice que es obligación del tribunal fundamentar las resoluciones que dictare. Esta fundamentación debe expresar sucintamente, pero con precisión, los motivos de hecho y de derecho en que se basaren las decisiones tomadas. Destacando esta misma norma que la simple relación de los documentos del procedimiento o la mención de los medios de prueba o de las solicitudes de los intervinientes no sustituirá en modo alguno la fundamentación.

\subsubsection{Lugar}

Ya observamos que la $\mathrm{CP}$ dispone en el art. $19 \mathrm{~N}^{\circ} 7$ letra d) que «nadie puede ser arrestado o detenido, sujeto a prisión preventiva o preso, sino en su casa o en lugares públicos destinados a este objeto». Por su parte, el art. 150 en su inc. $2^{\circ}$ establece que «la prisión preventiva se ejecutará en establecimientos especiales, diferentes de los que se utilizaren para los condenados $\mathrm{o}$, al menos, en lugares absolutamente separados de los destinados para estos últimos». En el inc. $3^{\circ}$ se reitera la idea de no tener en un mismo lugar a los jóvenes y no reincidentes con la población penitenciaria de mayor peligrosidad. Inclusive se permite excepcionalmente que el imputado pueda salir durante el día, ya sea por un período determinado o con carácter indefinido, siempre que se asegure convenientemente que no se vulnerarán los objetivos de la prisión preventiva. Norma, esta última, que se asemeja a la reclusión nocturna decretada respecto de un reo ya condenado. Lo más lógico en esta situación, sobretodo cuando fuese por tiempo indefinido, es que el tribunal deje sin efecto la prisión preventiva y eventualmente ordene otra medida cautelar personal.

La disposición que obliga a tener en establecimientos especiales a quienes se encontraren sujetos a prisión preventiva es de la mayor importancia. Es deseable que tan pronto como el presupuesto asignado al Ministerio de justicia lo permita se construyan estos establecimientos. No olvidemos que es el propio art. 150 en su inc. $3^{\circ}$ quien señala que «el imputado será tratado en todo momento como inocente». La persona privada de libertad por encontrarse sujeto a esta medida cautelar no debe ser enviada a los mismos lugares donde están cumpliendo su pena los sujetos ya condenados. Sabemos que en esta materia rige el principio de no culpabilidad, y una forma efectiva de materializar este principio es empezar por tener en distintos lugares a quienes ya fueron condenados, de aquellos que sólo están sujetos a una simple medida cautelar personal. 


\subsubsection{Tiempo}

Ya hemos observado que uno de los aspectos más negativos de la regulación de esta institución es su carácter indefinido, al no contemplarse bajo el NCPP un plazo máximo de duración. Con todo, veremos a continuación que, pese a ello, sí se contemplan en el NCPP una serie de artículos que permiten poner término a esta institución bajo determinados supuestos. Por de pronto, el art. 122 señala que estas medidas sólo duraran mientras se subsistiere la necesidad de su aplicación. Idea que es reafirmada por el art. 152 que dispone en su inc. $1^{\circ}:$ «El tribunal, de oficio o a petición de cualquiera de los intervinientes decretará la terminación de la prisión preventiva cuando no subsistieren los motivos que la hubieren justificado». Se pone de manifiesto que esta medida está sujeta a la denominada en doctrina cláusula rebus sic estantibus, es decir, la medida sólo debe mantenerse en la medida que subsista el peligro que se quiso evitar cuando fue acordada. Pero tan pronto como desaparezcan estas circunstancias el juez, de oficio o a petición de parte, debe ordenar su alzamiento. Así, por ejemplo, si la medida fue concedida porque existían diligencias precisas y determinadas de la investigación, tan pronto como ellas se lleven acabo (interrogar a testigos, recopilación de los elementos de prueba, informe pericial, etc.) el imputado debe ser puesto en libertad. Igualmente, si la prisión fue ordenada porque el imputado no compareció a la citación judicial, tan pronto se lleve adelante esta diligencia el sujeto debe quedar en libertad. Lo mismo se predica de los demás criterios por los cuales se puede privar al imputado de su libertad.

Pero la medida no sólo debe cesar cuando no subsistan los motivos que la hubieren justificado, sino que en el inc. $2^{\circ}$ del art. 152 se contempla una obligación para el tribunal, cual es, citar de oficio a una audiencia con el fin de considerar la cesación o la prolongación de la medida, cuando la duración de esta hubiere alcanzado la mitad de la pena privativa de libertad que se pudiere esperar en el evento de dictarse sentencia condenatoria, o de la que hubiese impuesto existiendo recursos pendientes.

Por su parte, el art. 144 señala que la «resolución que ordenare o rechazare la prisión preventiva será modificable de oficio o a petición de cualquiera de los intervinientes, en cualquier estado del procedimiento». Como se aprecia la ley faculta al juez para que de oficio deje sin efecto la medida decretada. Ahora bien, si el imputado solicita la revocación de la prisión preventiva el tribunal puede rechazar de plano esta solicitud. También puede citar a los intervinientes a una audiencia, con el fin de abrir debate sobre la subsistencia de los requisitos que autorizan la medida. En todo caso, no podrá desechar de plano la solicitud del imputado y deberá necesariamente citar a una audiencia para discutir sobre la continuidad de la medida, cuando hubieren transcurrido dos meses desde el último debate oral en que se hubiere ordenado o mantenido la prisión preventiva.

La posibilidad que el juez pueda decretar de oficio la prisión preventiva cuando esta hubiere sido rechazada, está condicionada a que el juez cite a una audiencia y existieren otros antecedentes que, a juicio del tribunal, justificaren discutir nuevamente su procedencia (inc. $3^{\circ}$ art. 144). No deja de ser curiosa, en todo caso, esta disposición que faculta al juez para proceder de oficio en esta materia. Máxime si tenemos presente que en conformidad con su redacción es el juez quien considera si existen nuevos antecedentes que justifican discutir nuevamente la procedencia de la medida. 
Por su parte el inc. 2 del art. 145 reafirma, una vez más, la preocupación del legislador porque la prisión preventiva esté continuamente en revisión a efectos de determinar si se justifica su prolongación o si, por el contrario, es necesario decretar la libertad del imputado. Así, dispone el referido inc. $2^{\circ}$ que «transcurridos seis meses desde que se hubiere ordenado la prisión preventiva o desde el último debate oral en que ella se hubiere decidido, el tribunal citará de oficio a una audiencia con el fin de considerar su cesación o prolongación». Es deseable, en todo caso, que no se llegue a privar de libertad bajo esta modalidad por tan vergonzoso plazo ${ }^{67}$.

Como vemos, el legislador impone al juez términos objetivos, seis meses desde que se hubiere decretado, o si hubiere petición del imputado dos meses desde el último debate oral, o en cualquier momento en que se hubieren modificado las circunstancias que se tuvieron presente para dictarla, en todos estos casos, el juez debe citar a una audiencia a efectos de discutir la cancelación de la medida.

\subsubsection{Efectos de la medida}

El principal efecto que se deriva de la prisión preventiva es el internamiento de la persona afectada por la medida en un establecimiento especial, con la consiguiente pérdida de su libertad personal. El art. 150 en su inc. $2^{\circ}$ establece que «la prisión preventiva se ejecutará en establecimientos especiales, diferentes de los que se utilizaren para los condenados $\mathrm{o}$, al menos, en lugares absolutamente separados de los destinados para estos últimos». Agrega en su inc. $3^{\circ}$ que el imputado «será tratado en todo momento como inocente», y que la prisión preventiva «se cumplirá de manera tal que no adquiera las características de una pena, ni provoque otras limitaciones que las necesarias para evitar la fuga y para garantizar la seguridad de los demás internos y de las personas que cumplieren funciones o por cualquier motivo se encontraren en el recinto». Ya hemos argumentado que esta es una disposición de la mayor importancia, y que si verdaderamente se desea que la prisión preventiva no se transforme en los hechos en la aplicación de una pena anticipada, se deben construir a la brevedad estos establecimientos especiales.

Esta idea es reiterada en el inc. $3^{\circ}$ del art. 152 que nos dice que «el tribunal deberá adoptar y disponer las medidas necesarias para la protección de la integridad física del imputado, en especial aquellas destinadas a la separación de los jóvenes y no reincidentes respecto de la población penitenciaria de mayor peligrosidad». En todo caso, poco podrán hacer los jueces si en la práctica no se cuenta con la infraestructura adecuada que permita materializar efectivamente esta disposición.

Si el imputado, sujeto a esta medida, fuere finalmente condenado a una pena privativa de libertad, el tiempo durante el cual estuvo en prisión se le abonará íntegramente al cumplimiento de la condena (art. 348).

Si se dicta sentencia absolutoria o sobreseimiento definitivo el preso debe ser puesto en libertad y tendrá derecho a reclamar las indemnizaciones del Estado que

\footnotetext{
${ }^{67}$ En el proyecto del ejecutivo este plazo era de cuatro meses. En el $2^{\circ}$ informe de la Comisión de Constitución, legislación y justicia del Senado se modificó este plazo por el de seis meses porque se estimó que «un lapso prudencial es de seis meses, para evitar el recargo de los tribunales». Tristemente a nuestros legisladores les preocupa más el atraso crónico de los tribunales del crimen de Santiago que las garantías de los potenciales «clientes» del sistema penal.
} 
correspondan (art. $19 \mathrm{~N}^{\circ} 7$ letra i) de la CP). No se olvide que la aplicación de esta disposición ha sido del todo excepcional según hemos señalado.

\subsubsection{Incomunicación}

La prisión preventiva puede revestir una doble forma: comunicada o incomunicada. La regla general es la comunicación, en la que el preso gozará de todos los derechos concedidos por la ley. Pero también el juez puede decretar la incomunicación del preso en conformidad con lo dispuesto en el art. 151. En este evento el fiscal puede pedir la incomunicación del preso y el juez decretarla hasta por un máximo de diez días, si considera que ello es necesario para el éxito de la investigación. Con todo bajo el NCPP no existe una incomunicación absoluta y el preso tiene derecho a entrevistarse privadamente con su abogado (art. 94 letra f). Del mismo modo tampoco se puede restringir el acceso a su propia atención médica (inc. $1^{\circ}$ art. 151).

En el inc. $2^{\circ}$ del art. 151 se señala que «el tribunal deberá instruir a la autoridad encargada del recinto en que el imputado se encontrare acerca del modo de llevar a efecto la medida, el que en ningún caso podrá consistir en el encierro en celdas de castigo». Parece inverosímil que el legislador tenga que prohibir expresamente esta situación, pero ello es necesario por la cultura autoritaria que ha existido en Chile tras largos años de vivir bajo dictadura y de tener vigente un sistema procesal penal abiertamente inquisitivo.

\subsubsection{Susitución de la prisión preventiva por otras medidas cautelares}

Dispone el inc. $1^{\circ}$ del art. 145 que «en cualquier momento del procedimiento el tribunal, de oficio o a petición de parte, podrá sustituir la prisión preventiva por alguna de las medidas que se contemplan en las disposiciones del párrafo $6^{\circ}$ de este título». Norma que en verdad no hace más que reiterar lo señalado por el inc. $2^{\circ}$ del art. 139 en el sentido que la prisión preventiva es la última de las medidas cautelares personales a las que puede acudir el tribunal para asegurar la comparecencia del imputado al juicio oral. Si cualquiera de las medidas cautelares previstas en el párrafo $6^{\circ}$ - a las que luego me referiré- son aplicables y cumplen la finalidad de asegurar la comparecencia del imputado, el tribunal debe preferir éstas a aquella. Por tanto, si el juez decidió conceder la prisión preventiva puede, posteriormente, en cualquier estado del proceso sustituirla por alguna de esas otras medidas cautelares personales que causan menos vejación en el imputado y que de igual modo aseguran la comparecencia del mismo al juicio oral. En todo caso, la estructura y lógica de las normas del NCPP debieran evitar llegar a esta situación, siendo preferible que el juez desde un comienzo no tenga necesidad de aplicar la prisión preventiva, sino que acuda directamente a las demás medidas cautelares personales que se contemplan en el NCPP. La lógica de estas disposiciones debiera llevar a una aplicación inversa de este artículo, esto es, primero deben concederse una o más de las medidas que se contemplan en el párrafo 6, y si ellas se han mostrado ineficaces el juez debiera, a petición de parte, citar a una audiencia y considerar su sustitución por la prisión preventiva.

\subsubsection{Reemplazo de la prisión preventiva por una caución económica}

El art. 146 dispone: «Cuando la prisión preventiva hubiere sido o debiere ser impuesta para garantizar la comparecencia del imputado al juicio y a la eventual ejecución de la pena, el tribunal podrá autorizar su reemplazo por una caución económica suficiente, cuyo monto fijará». Agrega en el inc. $2^{\circ}$ que «la caución podrá consistir en el depósito por 
el imputado u otra persona de dinero o valores, la constitución de prendas o hipotecas, o la fianza de una o más personas idóneas calificadas por el tribunal».

Esta disposición plantea algunas interrogantes; por de pronto ¿en qué casos procede esta sustitución?, ¿cuándo, efectivamente, el juez puede autorizar este reemplazo? $\mathrm{Si}$ nos fijamos con detención en este artículo se consagran expresamente los fines cautelares que en doctrina se aceptan para la prisión preventiva. Mágicamente aparecen de un modo expreso, para los efectos de sustituir la medida por una caución, los fines de garantizar la comparecencia del imputado al juicio y a la eventual ejecución de la pena.

La norma no deja de causar cierta perplejidad porque pudiere interpretarse que estos elementos aparecen como nuevos en relación con los criterios que contempla el art. 140 letra c) para ordenar la prisión preventiva. Por de pronto, ellos claramente no hacen alusión al criterio de peligrosidad para la seguridad del ofendido que contempla el aludido art. 140 en su letra c), ni tampoco al criterio de existir diligencias precisas y determinadas de investigación que, como sabemos, tiene por finalidad evitar la destrucción o alteración de medios probatorios ${ }^{68}$. En otras palabras, si la prisión preventiva hubiese sido ordenada por el juez teniendo como fundamento para ello el peligro para la seguridad del ofendido, o la existencia de diligencias precisas y determinadas de investigación, no procede el reemplazo de esta medida por una caución económica.

Ahora bien, en su momento señalamos que dentro del criterio de peligrosidad para la sociedad, en la forma que ha sido explicitado en el inc. $3^{\circ}$ del art. 140 , se apuntaban y recogían estos precisos fines cautelares, esto es, asegurar la presencia del imputado al juicio y, en su día, a la ejecución de la eventual sentencia condenatoria. Es, por tanto, bajo este criterio que principalmente procede el reemplazo de la prisión preventiva por una caución económica. Esta situación es la única que, dentro de los criterios recogidos en la letra c) del art. 140, permite que el imputado dando suficientes garantías de comparecencia al juicio y a la ejecución de la pena, pueda reemplazar la aplicación de tal medida por una caución económica ${ }^{69}$.

Fuera del ámbito del art. 140 letra c) sabemos que la prisión preventiva puede decretarse en aquellos casos de incumplimiento de ciertas obligaciones que la ley ha impuesto al imputado. En estas situaciones no hay duda que también procede el reemplazo de la prisión preventiva por una caución. La circunstancia que en todas esta situaciones posibilita la aplicación de esta medida cautelar es precisamente el peligro de fuga del imputado.

No se olvide que el art. 146 nos indica que el tribunal puede autorizar el reemplazo de la prisión preventiva por una caución cuando hubiere sido o debiere ser impuesta... Es decir, la caución tiene un claro fin preventivo y, por lo tanto, los jueces deben siempre tener presente que en la audiencia en que se discute la procedencia de esta medida, se puede, antes de imponerla, reemplazar su aplicación por una caución económica.

${ }^{68}$ Esto es en verdad de toda lógica; si existe peligro de que el imputado altere, modifique o destruya los medios de prueba, ¿qué función podría cumplir la caución en reemplazo de la prisión preventiva? Claramente ninguno. En lo que dice relación con el criterio de peligrosidad para la seguridad del ofendido ya hemos dicho que él se aparte de los fines cautelares de la prisión preventiva.

69 Comprendo que para aquellos que desconocen el carácter cautelar del criterio de peligrosidad para la sociedad nieguen, también, la posibilidad de reemplazar la prisión preventiva en esta circunstancia. 
En relación con el monto de la caución la ley no nos da más referencia que señalar que él debe ser suficiente. No establece ningún criterio que ayude al tribunal a determinar qué debe entenderse por suficiente, por lo que me temo que esta situación va a quedar sujeta a la completa discrecionalidad judicial. De ahí que debamos buscar algunos criterios que nos den cierta orientación. En este sentido, no olvidemos que el monto de la caución debe estar en estricta relación con la finalidad de la garantía: evitar la fuga del imputado. Al respecto puede servir de auxilio analizar los motivos por los cuales el juez ha decretado la medida. Así, si el criterio del tribunal fue el peligro para la seguridad de la sociedad porque el delito que se investiga reviste una especial gravedad, o si los antecedentes del imputado aumentan los temores de una eventual fuga, debe exigirse una caución más bien alta. Por el contrario, si el delito que se investiga no fuere grave, o si el imputado no tuviere antecedentes que permitan sospechar de su no comparecencia a la ejecución de la sentencia, creo que el monto de la caución debiera ser más bien bajo

Finalmente, hay que señalar que en relación con el tipo de caución, la ley acepta prácticamente cualquier caución sea esta del imputado o de un tercero. Así, puede consistir en el deposito de dineros o de valores, en la constitución de una hipoteca o de una prenda, o en la fianza de una o más personas idóneas calificadas por el tribunal.

\subsubsection{Ejecución de las cauciones}

La caución tiene por finalidad, según hemos dicho, asegurar la comparecencia del imputado al juicio y a la eventual ejecución de la pena. Por lo tanto, si el tribunal ha accedido al reemplazo de la medida cautelar por esta caución y el imputado finalmente no comparece al juicio, o se sustrae de la ejecución de la pena, procede que se ejecute la caución dada en garantía. El art. 147 se remite en esta materia «a las reglas generales». Entendemos que la remisión es las normas de realización que se contemplan en el CPC. El monto que se obtuviere se entregará a la Corporación Administrativa del Poder Judicial.

Ahora bien, si la caución la hubiere constituido un tercero, el tribunal debe poner en su conocimiento el hecho de que el imputado no ha comparecido al juicio o a la ejecución de la pena, apercibiéndolo con que si el imputado no comparece dentro de cinco días, se procederá a hacer efectiva la caución. La norma busca que este tercero colabore con la justicia, y que en la medida de sus posibilidades convenza al imputado de que debe presentarse ante el tribunal.

En ambos casos si la caución no consistiere en dinero o valores, actuará como ejecutante el Consejo de Defensa del Estado, para lo cual el tribunal procederá a poner los antecedentes en su conocimiento, oficiándole al efecto.

\subsubsection{Cancelación de la caución}

Ya hemos señalado que caución tiene una finalidad específica, asegurar la comparecencia del imputado al juicio y a la eventual ejecución de la pena Por tanto, si estos fines se encuentran satisfechos procede que se cancele la caución y se libere el correspondiente gravamen. De allí que el art. 148 señale que «la caución será cancelada y devuelto los bienes afectados, siempre que no hubieren sido ejecutados con anterioridad:

a) Cuando el imputado fuere puesto en prisión preventiva;

b) Cuando por resolución firme, se absolviere al imputado, se sobreseyere la causa o se suspendiere condicionalmente el procedimiento. 
c) Cuando se comenzare a ejecutar la pena privativa de libertad o se resolviere que ella no debiere ejecutarse en forma efectiva, siempre que previamente se pagaren la multa y las costas que impusiere la sentencia».

Las situaciones previstas por el legislador para cancelar la caución son de toda lógica. La situación prevista en la letra a) creo que será la manera usual de poner término a la caución. Si el imputado fuere puesto en prisión preventiva, ya sea por temor a la ejecución de las garantías que él personalmente hubiere ofrecido, o por convencimiento del tercero de verse expuesto al mismo riesgo, procede que se cancele la caución que ya ha cumplido su objetivo: asegurar la comparecencia del imputado al juicio. Los casos previstos en la letra b) son indicativos de que el sujeto no tiene responsabilidad penal. Por de pronto, la absolución del imputado y el sobreseimiento del mismo demuestra su completa inocencia y el término la pretensión penal en su contra. No hay ningún motivo para mantener la caución ${ }^{70}$. La suspensión condicional del procedimiento, una vez transcurrido el plazo que hubiere establecido el tribunal, produce el efecto de extinguir la acción penal, debiendo el tribunal de oficio o a petición de parte, dictar el sobreseimiento definitivo (art. 240). Finalmente, las situaciones previstas en la letra c) demuestran que la medida cumplió su objetivo y el imputado compareció a la ejecución de la pena, la cual ya se está ejecutando, o se resolvió que ella no debe ejecutarse en forma efectiva. La única obligación que la ley establece es que el condenado previamente pague las costas y las multas impuestas.

\subsubsection{Recursos}

Señala el art. 149 que la «resolución que ordenare, mantuviere, negare lugar o revocare la prisión preventiva será apelable cuando hubiere sido dictada en una audiencia. En los demás casos no será susceptible de recurso alguno».

Para entender esta norma debemos analizar las distintas hipótesis que ella regula. La resolución que ordena como la que niega la prisión preventiva son siempre apelables. Lo anterior porque la prisión preventiva, en cuanto medida cautelar, sólo puede ser adoptada en audiencia. No existe la posibilidad de que el tribunal decrete o rechace la petición de esta medida sin llamar a las partes una audiencia en la cual se discutirá la respectiva petición ${ }^{71}$.

Ahora bien, el art. 144 nos dice que la resolución que ordenare o rechazare la prisión preventiva será modificable de oficio o a petición de cualquiera de los intervinientes, en cualquier estado del procedimiento. Agregando, en el inc. $2^{\circ}$ que «cuando el imputado solicitare la revocación de la prisión preventiva el tribunal podrá rechazarla de plano [...]». Pues bien, en caso de que el tribunal rechace de oficio la petición de dejar sin efecto la medida concedida no procederá recurso alguno en contra de esta resolución. Si, por el contrario, previo a resolver la solicitud el tribunal cita a una audiencia para resolver la petición, la resolución que rechace la petición sí será apelable.

\footnotetext{
${ }^{70}$ Una vez comunicada a las partes la decisión absolutoria se ordenará en forma inmediata la cancelación de las garantías de comparecencia que se hubieren otorgado (art. 347). El sobreseimiento definitivo pone término al procedimiento con autoridad de cosa juzgada (art. 251).

71 De allí que el inc. final del art. 144 señale que «si la prisión preventiva hubiere sido rechazada, ella podrá ser decretada con posterioridad en una audiencia, cuando existieren otros antecedentes que, a juicio del tribunal, justificaren discutir nuevamente su procedencia» (la cursiva es mía).
} 


\subsubsection{Término de la prisión preventiva}

Dispone el inc. $1^{\circ}$ del art. 153 que «el tribunal deberá poner término a la prisión preventiva cuando dictare sentencia absolutoria y cuando decretare sobreseimiento definitivo o temporal, aunque dichas resoluciones no se encuentren ejecutoriadas». Por su parte, el art. 347 prescribe que «comunicada a las partes la decisión absolutoria [...], el tribunal dispondrá, en forma inmediata, el alzamiento de las medidas cautelares personales que se hubieren decretado en contra del acusado [...]».

En su momento, cuando vimos el carácter instrumental de las medidas cautelares, señalamos que ellas se extinguen cuando se pronuncia la providencia principal y ésta desarrolla su eficacia ejecutiva. Señalamos, igualmente, que si la demanda era desestimada la medida perdería toda su eficacia y debía desaparecer del orden procesal. Las disposiciones transcritas en el párrafo precedente precisamente reconocen esta característica respecto de la prisión preventiva. Si el proceso finaliza con una sentencia absolutoria, o si previamente se ha dictado sobreseimiento en la causa, las medidas cautelares que se hubieren adoptado deben cesar de inmediato. La pretensión punitiva se ha mostrado infundada y, por tanto, nada justifica que se mantenga la prisión preventiva que aseguraba su ejecución. En este caso, una vez que se hubiere dictado sentencia absolutoria o sobreseimiento temporal o definitivo, aun cuando no estén ejecutoriados, debe ponerse en libertad al sujeto preso.

Asimismo, cuando vimos el carácter provisional de las medidas cautelares indicamos que ellas no tienen vocación de perdurar indefinidamente en el tiempo, sino que son provisionales en su naturaleza y no aspiran jamás a convertirse en definitivas. Pues bien, sabemos que la filosofía del NCPP es la continua revisión de los presupuestos que tuvo presente el juez para decretar la prisión preventiva. Sin embargo, pudiere ocurrir que pese a esta continua revisión la prisión preventiva hubiere permanecido vigente durante todo el proceso. No quiere decir esto que la medida pierda su carácter provisional. Y no lo pierde porque precisamente hay en momento en el proceso en el cual necesariamente debe cesar. Este momento se da cuando se dicta la sentencia absolutoria o sobreseimiento de la causa $^{72}$.

Ahora bien, en una norma de extrema cautela el inc. $2^{\circ}$ del art. 153 dispone que en estos caso «se podrá imponer alguna de las medidas señaladas en el párrafo $6^{\circ}$ de este título, cuando se consideraren necesarias para asegurar la presencia del imputado». La cautela se debe a que ni la sentencia absolutoria, ni el sobreseimiento definitivo decretados, se encuentran ejecutoriados. Aun existe, por tanto, el riesgo de que estas resoluciones sean revocadas por la interposición de algún recurso. El legislador entiende que el tribunal a quo puede equivocarse en la apreciación de los hechos y, por tanto, lo faculta para aplicar otra medida cautelar que siendo menos drástica que la prisión preventiva, también garantice la presencia del imputado al juicio.

\subsubsection{Otras medidas cautelares personales}

Bajo una denominación poco comprometedora se regula en el NCPP si quizás uno de los mayores aciertos en esta materia. En efecto, en los arts 155 y 156 se

72 Por cierto también si se dictare sentencia condenatoria porque en ese evento la ejecución de la pena reemplaza a la medida cautelar. 
contemplan una serie de medidas a las que puede acudir el juez de garantía con preferencia a la prisión preventiva. Estas «otras» medidas cautelares son el corolario lógico y necesario de los principios que hemos visto informan la aplicación de la prisión preventiva: subsidiaridad y proporcionalidad. Son estas «otras medidas» las que principalmente van a permitir que estos principios en la práctica reciban un efectivo empleo. De poco o nada hubiese servido establecer dichos principios si en definitiva no se hubiere entregado al juez la facultad real de ponderar en cada caso qué tipo de medida satisface y resguarda mejor los fines del procedimiento. Si sólo se hubiese consagrado el binomio «prisión preventivalibertad» la actividad del tribunal hubiere quedado severamente restringida.

\subsubsection{Casos en que proceden}

El art. 155 contempla tres situaciones que hacen procedente una o más de estas medidas cautelares. Así, dispone la norma citada que para garantizar: (a) el éxito de las diligencias de investigación; (b) proteger al ofendido; o (c) asegurar la comparecencia del imputado a las actuaciones del procedimiento o ejecución de la sentencia, el tribunal a petición del fiscal, del querellante o de la víctima, podrá imponer al imputado una o más de las medidas que la propia norma indica.

Como vemos las dos primeras situaciones que hacen procedente estas medidas son muy parecidas a dos de los elementos que facultan al tribunal para decretar la prisión preventiva. Allá la ley habla de diligencias precisas y determinadas de investigación, acá de diligencias de investigación. Allí habla de peligro para la seguridad del ofendido, aquí de proteger al ofendido. En el fondo, más allá del matiz en las palabras utilizadas por el legislador, no hay inconveniente en equiparar estas dos situaciones con las contempladas a propósito de la prisión preventiva y, por tanto, equiparar los fines que cada una puede cumplir.

En la tercera situación prevista por el art. 155, la ley se aparta de la literalidad del texto de la prisión preventiva y aparecen los fines propiamente cautelares que la doctrina señala deben cumplir estas medidas: asegurar la comparecencia del imputado a las actuaciones del procedimiento o a la ejecución de la sentencia. ¿Puéden reconducirse estos fines al peligro para la seguridad de la sociedad que se contempla en la prisión preventiva? La respuesta en parte ya la conocemos. Cuando analizamos el contenido que el inc. $3^{\circ}$ del art. 140 ha dado a esta frase, y cuando analizamos los casos en que procedía el reemplazo de la prisión preventiva por una caución económica, señalamos que el objetivo del legislador al configurar tal criterio de peligro para la sociedad era evitar la fuga del imputado, y, por tanto, asegurar su comparecencia a las actuaciones del procedimiento y a la ejecución de la sentencia. Por tanto, creo que sí pueden reconducirse estos fines a los resguardados por el peligro para la sociedad. En definitiva, estas medidas satisfacen los mismos fines que la prisión preventiva pero de una forma menos gravosa para el imputado, y mucho más en armonía con el principio de no culpabilidad que rige en esta materia.

Finalmente, el art. 155 dispone que la solicitud para la aplicación de alguna de estas medidas cautelares debe ser efectuada por el fiscal, el querellante o la víctima. Una vez hecha la petición la ley faculta al tribunal para imponer una o más de estas medidas según resultare adecuado para cada situación. El legislador, como vemos, amplía el horizonte de posibilidades de que dispone el tribunal y facilita la protección de los diversos tipos de periculum que estas medidas cubren. Por tanto, dependiendo del peligro que se desea evitar se puede pedir y adoptar más de una medida cautelar. Lógicamente, nada 
impide que el solicitante de la medida indique un orden de preferencia en su petición, pero en última instancia quién decide será el tribunal.

\subsubsection{Enumeración}

Las medidas cautelares que se contemplan en el art. 155 son las siguientes:

a) La privación de libertad, total o parcial, en su casa o en la que el propio imputado señalare, si aquella se encontrare fuera de la ciudad asiento del tribunal;

b) La sujeción a la vigilancia de una persona o institución determinada, las que informarán periódicamente al juez;

c) La obligación de presentarse periódicamente ante el juez o ante la autoridad que él designare;

d) La prohibición de salir del país, de la localidad en la cual residiere o del ámbito territorial que fijare el tribunal;

e) La prohibición de asistir a determinadas reuniones, recintos o espectáculos públicos, o de visitar determinados lugares;

f) La prohibición de comunicarse con personas determinadas, siempre que no se afectare el derecho a defensa, y

g) La prohibición de aproximarse al ofendido o su familia y, en su caso, la obligación de abandonar el hogar que compartiere con aquel.

Como vemos, estas medidas pueden llegar a cumplir fines similares a los de la prisión preventiva. Así, las situaciones contempladas en los en las letras a), b), c) y d), resguardan del peligro de fuga del imputado que nosotros hemos identificado con el peligro para la seguridad de la sociedad en la prisión preventiva. Las letras a) y f) protegen del peligro de destrucción de los medios de prueba que equivale a las diligencias precisas y determinadas de la prisión preventiva. Finalmente, la situación regulada en la letra g) se equipara al peligro de seguridad del ofendido de la prisión preventiva.

\subsubsection{Oportunidad}

Lo único que la ley señala sobre este particular es que el tribunal puede decretar estas medidas después de formalizada la investigación. En esta materia rige la misma situación que para la prisión preventiva. Por tanto, el fiscal, el querellante, o la víctima podrán pedir la aplicación de una o más de estas medidas en cualquiera de las audiencias que hemos visto puede solicitarse la prisión preventiva, esto es, en la de formalización, en la de preparación del juicio oral; en la del juicio oral, o en una especialmente citada para este efecto.

\subsubsection{Suspensión temporal de la medida}

Señala el art. 156 que el tribunal puede a petición del afectado dejar temporalmente sin efecto las medidas adoptadas, cuando estimare que no se ponen en peligro los objetivos que se tuvieron presente al concederlas. En este caso el juez debe oír al fiscal y previamente citar a los demás intervinientes que hubieren participado en la audiencia en que fueron decretadas. Para estos efectos el juez puede admitir las cauciones previstas en el art. 146.

Una vez más el legislador reitera una idea que está presente en toda la regulación de las medidas cautelares personales: sólo deben imponerse cuando ello fuere 
absolutamente indispensable para asegurar los fines del procedimiento, y sólo deben durar mientras subsista la necesidad de su aplicación. En este caso, la persona afectada por alguna o algunas de estas medidas puede pedir al tribunal que suspenda su aplicación. No es difícil imaginar situaciones en las que será completamente inocuo para los fines del procedimiento suspender la aplicación de estas medidas. Máxime si tenemos presente que la ley faculta al tribunal para reemplazar la o las medidas decretadas por una caución económica. Así, por ejemplo, la posibilidad de participar en un evento cuando se está privado de libertad (un funeral, por ejemplo), de asistir por breve tiempo a un determinado lugar, de suspender la obligación de presentarse periódicamente a la autoridad, o, incluso, de viajar al extranjero cuando exista un motivo urgente y justificado (un tratamiento médico, por ejemplo), y los casos pueden ser infinitos, son todas situaciones que muestran lo conveniente de esta disposición.

El tribunal debe necesariamente escuchar la opinión del fiscal y de los demás intervinientes que hubieren participado en la audiencia en que se decretaron las medidas. Las obligaciones que el legislador impone al juez son muy claras: oír la opinión del fiscal y la de quienes participaron en la audiencia en que se ordenó la medida. De allí que si en el correspondiente proceso penal hay un querellante y éste no participó en la audiencia en que se ordenó una o más de estas medidas, el juez no debe oírlo.

Finalmente, dispone el inc. final del art. 155 que en relación con la procedencia, duración, impugnación y ejecución de estas medidas, regirán las disposiciones aplicables a la prisión preventiva, en cuanto no se opusieren a lo previsto en los arts. 155 y 156. Normas que ya hemos estudiado y las cuales nos remitimos.

\section{CONCLUSIÓN}

La regulación de las medidas cautelares personales constituye un significativo avance en relación con la anterior legislación que regía (y que aun rige en alguna parte del territorio de Chile) esta materia. Tanto en su configuración dogmática, en los requisitos para concederla, como en los plazos previstos para cada una de ellas (citación, detención, prisión preventiva y las otras medidas cautelares) se aprecia una sustancial mejora. En este sentido, la inclusión de las denominadas otras medida cautelares constituye, sin duda, uno de los mayores aciertos en esta materia. Son estas otras medidas las que debieran permitir a los jueces hacer una aplicación real y efectiva de los principios que informan a la prisión preventiva.

Tratándose de esta última medida, no obstante haberse conservado los criterios constitucionales de peligrosidad para la sociedad y el ofendido, y las diligencias de investigación, toda la regulación que efectúa el NCPP nos muestra la enorme preocupación que ha tenido el nuevo legislador por resguardar debidamente las libertades de los ciudadanos y los derechos del imputado. En primer lugar en esta materia rigen importantes principios que el juez debe tener siempre presente al momento de pronunciarse sobre su procedencia (no culpabilidad, subsidiaridad, proporcionalidad, juridicidad, contradicción, etc.). En segundo lugar, una vez que la medida ha sido adoptada, el legislador busca que su aplicación sea lo menos gravosa para el imputado, y que dure lo estrictamente indispensable para asegurar los fines del procedimiento. Así, el código contempla una serie de instituciones que permiten al tribunal examinar en cada instante su continuidad (revisión de oficio por el tribunal, obligación de revisión cada seis meses, cláusula rebus sic stantibus, reemplazo por una caución, sustitución por otra medida cautelar, 
etc.). Finalmente, aparecen como objetivos de esta medida, aun cuando de manera algo tímida y dispersa en el código, los estrictos fines procesales que ella debe cumplir, abandonando el legislador nacional la tentación de utilizar esta medida como una auténtica pena anticipada. Es de esperar que los tribunales chilenos comprendan el trascendental cambio que en esta materia ha operado, y no se dejen llevar por la tradicional cultura autoritaria que, aun en democracia, ha regido Chile. 